IZA DP No. 4669

Investor Protection and the Value of Shares:

Evidence from Statutory Rules Governing Variations of Shareholders' Class Rights in Russia

Alexander Muravyev

December 2009 


\title{
Investor Protection and the Value of Shares: Evidence from Statutory Rules Governing Variations of Shareholders' Class Rights in Russia
}

\author{
Alexander Muravyev \\ IZA, DIW Berlin \\ and St. Petersburg University
}

Discussion Paper No. 4669

December 2009

\author{
IZA \\ P.O. Box 7240 \\ 53072 Bonn \\ Germany \\ Phone: +49-228-3894-0 \\ Fax: +49-228-3894-180 \\ E-mail: iza@iza.org
}

\begin{abstract}
Any opinions expressed here are those of the author(s) and not those of IZA. Research published in this series may include views on policy, but the institute itself takes no institutional policy positions.

The Institute for the Study of Labor (IZA) in Bonn is a local and virtual international research center and a place of communication between science, politics and business. IZA is an independent nonprofit organization supported by Deutsche Post Foundation. The center is associated with the University of Bonn and offers a stimulating research environment through its international network, workshops and conferences, data service, project support, research visits and doctoral program. IZA engages in (i) original and internationally competitive research in all fields of labor economics, (ii) development of policy concepts, and (iii) dissemination of research results and concepts to the interested public.
\end{abstract}

IZA Discussion Papers often represent preliminary work and are circulated to encourage discussion. Citation of such a paper should account for its provisional character. A revised version may be available directly from the author. 
IZA Discussion Paper No. 4669

December 2009

\section{ABSTRACT \\ Investor Protection and the Value of Shares: Evidence from Statutory Rules Governing Variations of Shareholders' Class Rights in Russia*}

This paper uses a quasi-experimental framework provided by recent changes in Russian corporate law to study the effect of investor protection on the value of shares. The legal change analyzed involves the empowerment of preferred (non-voting) shareholders to veto unfavorable changes in their class rights. Based on a novel hand-collected dataset of dual class stock companies in Russia and using the difference-in-difference estimator, the study finds a statistically and economically significant effect of improved protection of preferred shareholders on the value of their shares. The result is robust to several changes in the empirical specification.

JEL Classification: $\quad$ G30, G38, K22

Keywords: investor protection, company law, dual class stock, class rights, Russia

Corresponding author:

Alexander Muravyev

IZA

P.O. Box 7240

53072 Bonn

Germany

E-mail: muravyev@iza.org

\footnotetext{
* This paper has benefited from comments and suggestions by Sudipto Bhattacharya, Mark Schaffer, Carsten Sprenger, and Oleksandr Talavera; by participants of the 2009 EEA conference in Barcelona as well as by participants of research seminars at St. Petersburg University Graduate School of Management, International College for Economics and Finance of Higher School of Economics (Moscow), and DIW Berlin. The usual caveat applies.
} 


\section{Introduction}

In the last few decades, scholars in economics, finance, and law have taken a growing interest in the effect of investor protection - which comes from law, stock exchange regulations, and firm-level provisions - on corporate governance and performance. Initially, the debate concentrated on the role of formal law, with two broad views on the subject-matter gradually crystallizing in the literature. One perspective suggests that corporate law is largely unnecessary because sophisticated suppliers and users of capital choose the efficient level of investor protection via private contracting (Grossman and Hart 1980; Easterbrook and Fischel 1991). Originating in the Coase (1960) theorem, it crucially relies on the assumption of costless contracting and well-functioning enforcement institutions. Corporate law may be trivial because many of its rules are market mimicking while others are avoidable, changeable, or unimportant (Black 1990). The other perspective emphasizes high payoffs from opportunistic behavior, as well as expensive and imperfect enforcement of contracts, which create incentives for users of capital to expropriate investors. In such circumstances, it is argued, explicit law can reduce the enforcement costs and restrain opportunistic behavior by providing standard form contracts for the parties involved (Coffee 1989; Mahoney 1995).

The debate about the role of investor protection and corporate law in particular was given a new impetus with the emergence in the late 1990s of the empirical "law and finance" literature (La Porta et al. 1997, 2000; La Porta, Lopez de Silanes, and Shleifer 1998). Based on cross-country comparisons, these studies have established a link between corporate law and the regulatory environment on the one hand and access to finance, corporate ownership, and company valuation on the other. More recently, there is a growing international literature analyzing the impact of changes in legal protection in a particular jurisdiction on shareholder returns and company value (Nenova 2006; Black and Khanna 2007; Litvak 2007). The Sarbanes-Oxley Act (SOX), passed in the US in the aftermath of the financial scandals and bankruptcies that unfolded at the turn of the century, is one of the most studied legal changes of this type (Li, Pincus, and O. Rego 2008; Jain and Rezaee 2006; Zhang 2007; Chhaochharia and Grinstein 2007; Wintoki 2007). Another rapidly developing field of research deals with corporate governance practices adopted by firms in order to protect investors (Gompers, Ishii, and Metrick 2003; Bebchuk, Cohen, and Ferrell 2004; Dahya and McConnell 2007). These strands of literature are bridged together in studies that ask how firm-level provisions interact with legal protection at the country level, including the cases when firms opt out of corporate law in order to provide better protection to their investors (Klapper and Love 2004; Bruno and Claessens 2007; Bergman and Nikolaevsky 2007). 
Despite these numerous contributions, the empirical evidence concerning the importance of investor protection for corporate governance and performance is far from being conclusive (Black and Khanna 2007). This is partly due to serious modeling challenges facing empirical research in the field, among which identification of the causal effect of investor protection stands out. Indeed, cross-country studies such as La Porta et al. (1998), which have generated the strongest evidence of the importance of legal protection to date, suffer from endogeneity problems, in particular, due to the omission of confounding factors at the country level (Costa and Mello 2006). Endogeneity problems also plague studies that analyze corporate governance practices at the firm level. A fast growing firm, for example, may adopt better governance practices in order to ensure access to external financing at a lower cost (Klapper and Love 2004). The causation may, therefore, run not only from investor protection to firm performance, but also the other way around.

Identification based on changes in law in a particular jurisdiction has also proved to be difficult because such changes typically apply to all firms at the same time, which makes it difficult to establish a counterfactual outcome, against which the effect of the policy intervention is to be evaluated. ${ }^{2}$ Event studies, which are often used in the corporate finance literature in such circumstances, cannot perfectly rule out contemporaneous confounding factors. In addition, ambiguities associated with choosing appropriate event windows may lead event studies to opposite conclusions about the same policy interventions. For example, recent research by Zhang (2007) and Litvak (2007) finds a total negative effect of SOX on firm value while both Li et al. (2008) and Jain and Rezaee (2006) report a total positive effect, with some indication that the difference in the findings may be due to the different event windows chosen (Chhaochharia and Grinstein 2007; Li et al. 2008). ${ }^{3}$

This paper takes advantage of an experimental framework provided by recent changes in statutory rules governing dual class stock in Russia to study how legal protection affects share prices. Specifically, it investigates the effect of introducing a mandatory rule that can unambiguously be interpreted as an improvement in the protection of preferred (non-voting) shareholders in Russian companies with dual class stock. The law change considered took effect in January 2002 and endowed preferred shareholders with the right to veto any

\footnotetext{
${ }^{2}$ Few studies identify the causal effect of improved investor protection by exploiting various types of "natural experiments", which generate well-defined treatment and control groups (embracing, respectively, firms that are affected and those that are not affected by changes in law). These include Black, Jang and Kim (2006), Black and Khanna (2007), and Litvak (2007), among others.

${ }^{3}$ In addition, studies of changes in corporate law usually say little about specific provisions and norms, because law changes come in packages. As shown by Bebchuk et al. (2004), not all provisions may matter in corporate governance.
} 
decisions of the shareholder meeting that could adversely affect their "class rights". 4 Importantly, the statutory change did not affect all dual class stock companies in the same way. Some corporate charters already contained the veto provision by the time the company law was altered in 2001. In statistical terms, this allows the researcher to divide all Russian firms with dual class stock into the treatment and control groups, the former embracing companies that were affected by the statutory change and the latter including companies that were not affected. These unique features of the country's company law and dual class firms provide an excellent opportunity for identification of the causal effect of legal protection on stock values.

The paper is based on a novel hand-collected dataset of Russian dual stock companies that combines the 2000-2002 share trade data from the Russian Trading System (RTS) stock exchange with additional information from companies' charters and quarterly reports to the Federal Financial Market Service (FFMS). We focus on the effect of the statutory change on the value of preferred (non-voting) stock. The latter is measured relative to the value of common shares, using the "voting premium" approach. This has two virtues. First, from the substantive viewpoint, the voting premium may be directly related to the risk of expropriation of non-voting shareholders (Goetzmann et al. 2002) and to private benefits of control (Dyck and Zingales 2004), which investor protection aims to curtail (La Porta et al. 2000). Second, from the econometric perspective, using the relative value of preferred stock is similar to additional differencing in that it helps eliminate idiosyncratic characteristics of firms that affect prices of both classes of shares.

Our main empirical results are derived from a multivariate regression analysis using several versions of the difference-in-difference (DID) estimator, including one with firm fixed effects and another one based on the median regression. The results show a statistically and economically significant effect of introducing a mandatory rule that protects preferred shareholders on the value of preferred stock. In particular, our estimates suggest that the premium on voting shares in Russian dual class stock companies comprising the treatment group declined by about 30 percentage points (relative to the average of 146 percent observed in the full sample in 2001) as a consequence of the statutory change and this result holds for a number of alternatively defined pre- and post-treatment periods. It should, however, be acknowledged that the legal change considered explains a relatively small fraction of the overall variation of the voting premium in 2000-2005 (according to Muravyev (2009), the

\footnotetext{
${ }^{4}$ These include, for example, preferred shareholders' dividend entitlements and their special rights in the event of reorganization and liquidation of the company.
} 
premium was continuously falling from about $200 \%$ in 2000 to mere $45 \%$ in 2005) and therefore played only a limited role in the development of corporate governance in Russia.

The major strength of this paper stems from its identification strategy, which exploits an exogenous change in law affecting a clearly defined sub-sample of firms. This allows estimation of the causal effect of investor protection on the value of shares, which many previous studies found difficult to identify (Black and Khanna 2007). The paper contributes to the literature by documenting a key role of law and in particular, of its mandatory rules, in restraining shareholder expropriation and boosting share prices. It also highlights the importance of legal mechanisms protecting against "class rights" changes in companies with multiple classes of stock that deviate from the one share - one vote principle, a topic that has largely been overlooked in the literature. Because the paper focuses on Russia, a country which has been notoriously known for inefficient enforcement of law, its findings may also be useful in the ongoing debate concerning the role of formal law in the weak enforcement environment (Pistor, Raiser, and Gelfer 2000; Berglof and Claessens 2004; Nenova 2006). The present analysis suggests that law on the books may work even when law enforcement is far from perfect. The paper also extends international literature on investor protection, private benefits of control, and dual class shares, which still lacks systematic evidence from Russia despite the remarkable developments in its emerging stock market during the last decade. ${ }^{5}$

The rest of the paper is organized as follows. Section 2 introduces the major features of dual class stock in Russia and discusses the 2001 statutory change. Section 3 outlines the methodological approach. Section 4 describes the data and the sample. Section 5 presents the empirical results. Section 6 concludes.

\section{Dual class stock, “class rights” and corporate law changes in Russia}

Deviations from the "one share-one vote" principle are common in the corporate world and often occur through the issue of dual class stocks (Adams and Ferreira 2008). The implications of the company's decision to use different types of shares have been extensively studied (e.g., Harris and Raviv 1988; Hart 1995). It has been conjectured that the extreme separation of cash flow rights from control rights that results from the issue of non-voting stocks is fraught with inefficient corporate governance and, in particular, with expropriation of investors in non-voting stocks. Under an extreme scenario, a company may simply divert the cash flow from the non-voting shareholders to the benefit of the managers and, possibly, of the voting shareholders.

\footnotetext{
${ }^{5}$ Goetzmann, Spiegel, and Ukhov (2003), Black, Love and Rachinsky (2006), Dyck, Volchkova, and Zingales (2008) and Muravyev (2009) are among the few exceptions in this regard.
} 
These expropriation concerns explain the considerable attention paid to dual class stock in corporate law, as well as in the rules imposed by the world's stock exchanges. While outright bans of dual class stock are uncommon, the deviations from the "one share-one vote" principle are subject to substantial regulation (Burkart and Lee 2008). Legal provisions concerning shareholder "class rights" usually come in two major forms. In some countries, especially those belonging to the civil law tradition, corporate law strictly regulates the number and the type of different classes of shares that can be issued. It also links the dividend and other features of non-voting or restricted voting shares to the analogous features of voting shares. ${ }^{6}$ In more flexible regulatory environments, typical of common law countries, companies have considerable freedom in defining, in their charters, the rights attached to different types of shares. However, corporate law typically requires that a company's decision involving variation in the rights attached to a particular class of shares should to be approved by the holders of that class of shares. ${ }^{7}$ The evidence on the economic consequences of various legal provisions protecting non-voting and restricted voting shareholders is however scarce: it remains to be seen whether and how they affect shareholder welfare and the corporate sector at large.

In Russia, the rules governing dual class shares have undergone a number of drastic changes, despite the extremely short history of the development of the country's corporate law and stock market. The story starts in 1992, when the country launched an unprecedented privatization program aimed at transferring state enterprises to private ownership. During this process, large production units were to be converted into joint-stock companies, a legal form that was virtually unknown in the USSR until its very collapse in 1991. Most companies offered for privatization issued common shares only, but larger and more capital intensive firms ended up issuing both common (voting) and preferred (non-voting) shares, the two classes of stock that were authorized in the legislation. Preferred shares, which could comprise up to 25 percent of a company's equity, were initially distributed for free among company employees and retirees, with outside investors accumulating considerable blocks only later. ${ }^{8}$

\footnotetext{
${ }^{6}$ For example, the German company law (Aktiengesetz 1965) does not allow companies to issue shares with differential voting rights, except for a special class of stock called preference shares. These are entitled to preferences in regard to the distribution of dividends and liquidation proceeds and convey all other shareholder rights without exception.

${ }^{7}$ For example, the UK company law (Companies Acts 1985, 2006) requires that variations in class rights are to be approved in writing by holders of three-quarters of the issued shares of that class or by a resolution passed at a separate general meeting of the holders of that class of shares.

${ }^{8}$ See Blasi, Kroumova, and Kruse (1997) and Hare and Muravyev (2003) for details about Russia's privatization.
} 
Russia’s privatization process imposed a uniform (henceforth called "standard") corporate charter on virtually all newly established companies, which specified, among other things, the rights attached to the two classes of shares. ${ }^{9}$ The rights attached to common (voting) stock were quite similar to those existing in most other jurisdictions (they are basically restricted to the right to vote at shareholder meetings and the right to receive dividends, which are indefinite). The status of preferred shares was, in contrast, rather peculiar. While sharing a number of features with common shares, they did not confer general voting rights but instead provided a number of pecuniary privileges to their owners. In particular, companies with dual class stock were required to allocate at least 10 percent of their net profit to dividends on preferred shares (henceforth the 10 percent dividend rule). In addition, the dividend on preferred shares was bounded below by the dividend on common stocks. Preferred shareholders were also granted superior rights in the event of company liquidation. Importantly, the standard charter stipulated temporary enfranchisement of preferred shares in the case the dividend on them was not paid or was not paid in full, and it also endowed preferred shareholders with the right to vote on all decisions that involved their “class rights”. Effectively, preferred shareholders were granted veto power on decisions that concerned their class rights, as such decisions required a supermajority (two-thirds) approval by these investors.

The legal landscape regulating the creation and operation of companies in Russia was considerably changed with the adoption of the first version of the law on joint-stock companies in December $1995 .{ }^{10}$ Among an extensive list of new rules, the law introduced a much more flexible regime for the design of preferred (non-voting) shares, by not restating many of the mandatory rules previously included in the standard charter. For example, both the 10 percent dividend rule and the lower bound on preferred share dividends were not confirmed in the new law. It only required firms issuing preferred stock to determine (in their charters) the dividend on preferred shares, either as a fixed amount, a percentage of net profit, or any other strictly defined way. Similarly, the law did not confirm the mandatory nature of the veto power of preferred shareholders against "class rights" changes, a provision that was

\footnotetext{
${ }^{9}$ See Presidential Decree No. 721 dated 1 July 1992 "On organizational measures on transformation of state enterprises and voluntary associations of state enterprises into joint-stock companies”.

${ }^{10}$ Federal law “On joint-stock companies” N 208 FZ, dated 26 December 1995. Black and Kraakman (1996) provide a detailed discussion of the principles underlying the design of the new law as well as of its specific provisions. For example, the law delineated the rights and responsibilities of general shareholder meetings, of supervisory boards, and of management boards, introduced cumulative voting in the election of supervisory boards, as well as banned CEOs from holding the position of the supervisory board chairman.
} 
an integral part of the standard charter. ${ }^{11}$ Importantly, the law not only made many of the previously mandatory rules optional, but also contributed, as we explain below, to the differentiation among Russian firms with respect to maintaining the veto power of preferred shareholders in their charters.

The passage of the new law in 1995 made many of the norms contained in the standard corporate charter invalid. Because of that, the law explicitly obliged companies to bring their charters in conformity with the new regulations by 1 July 1996. However, in early 1996 it became clear that many firms faced considerable difficulties in implementing these changes due to the enormous scope of legal work and their lack of experience with corporate law. One response to the problem came from the legislator: the deadline for charter changes was moved to 1 July $1997 .^{12}$ The other response came from the firms themselves. Many companies changed their charters, including articles referring to preferred shares, using the exact wordings from the new law, thus essentially resorting to the "copy-paste approach". Others, however, were more selective and changed only those provisions that were in direct conflict with the law. The result was the emergence in 1996-1997 of two types of companies, those with and those without the veto power of preferred shareholders incorporated in their charters. $^{13}$

The second important statutory change that strongly affected preferred shareholders came in August 2001 with the amendments in Russian corporate law aimed at improving minority shareholder protection (henceforth it will be referred to as the second version of the law). ${ }^{14}$ A crucial change affecting preferred shareholders as a separate group was that, while

\footnotetext{
${ }^{11}$ Now, in case of corporate charter amendments that involved interests of preferred shareholders, the law guaranteed them just one vote per share in a joint voting with common shareholders. As preferred shareholders never held more than 25 percent of equity, they could no longer block any resolutions of the shareholder meeting, even those requiring supermajority (two-thirds) approval.

${ }^{12}$ With this purpose, a special law was passed by the parliament on 13 June 1996, just a few weeks before the originally envisaged deadline (Federal Law N 65 FZ).

${ }^{13}$ According to some estimates, about one-half of the companies that had issued preferred shares eliminated the rule on the veto power of preferred shareholders from their charters in the mid-1990s (Securities Market, 1998). The reasons for retaining or removing this rule, however, are not clear-cut. The fact that many companies simply copied entire paragraphs/articles from the new law into their corporate charters (instead of a careful and minimalist adaptation of the charters to the new requirements) suggests a significant role played by the lack of firms' experience in and familiarity with corporate law and corporate governance in the mid-1990s. Importantly, casual evidence casts doubts on the supposition that the decision to abolish the veto power of preferred shareholders was driven by corporate control reasons. This is best illustrated by the example of two largest groups of firms with dual class stock, regional telecommunication companies and regional power utilities. Even though both groups of firms were majority controlled by government via state holdings, "Svyazinvest" and "Unified Energy Systems", respectively, they behaved remarkably differently with regard to the veto power. In particular, most (but not all) regional telecommunication companies did abolish the rule while most (but not all) regional power utilities preserved it in their charters. While a thorough investigation of the reasons underlying the firms' decisions to retain or abolish the veto rule is extremely difficult, if not impossible, due to the virtual absence of information on Russian companies from the mid-1990s (which stems from exceptionally bad disclosure standards at that time), we attempt to shed more light on this issue when discussing our main findings. ${ }^{14}$ Federal law N 120 FZ dated 7 August 2001.
} 
still having no general voting rights, they regained the right to veto disadvantageous "class rights” changes. Starting from January 2002, such changes require supermajority (threequarters) approval of all preferred shareholders, and their votes are to be counted separately from the votes of common shareholders. The incorporation of this mandatory rule in the existing law represents an unambiguous improvement in the protection of preferred shareholders. Appendix 1 provides the exact wording of the relevant articles in the standard corporate charter (1992), as well as in the first and second versions of the company law passed in 1995 and 2001, respectively. ${ }^{15}$ Appendix 2 shows the timing of the legislative process leading to the adoption of the 2001 statutory change.

To summarize, since their introduction in 1992, preferred shares have enjoyed a number of advantages of a pecuniary character over common shares. The apparent disadvantage has been the absence of voting rights and, crucially, the possibility of "class rights” changes detrimental to preferred shareholders, especially after the adoption of the law on joint-tock companies in 1995. Indeed, the late 1990s saw numerous examples of expropriation of preferred shareholders as a class. ${ }^{16}$ In Russia, a country notoriously known for massive violation of shareholder rights as rigorously shown in Dyck et al. (2008), preferred shareholders were at a particular disadvantageous position facing higher risks of expropriation compared with minority investors in common stock. These risks were reduced in 2001 when the veto power of preferred shareholders was reintroduced by law. The rest of the paper takes a closer look at the effect of improved protection of preferred shareholders due to the 2001 statutory change on the value of preferred stock.

\section{Methodology}

As described in Section 2, in the mid-1990s, Russian dual-class stock companies evolved into two groups, one group that granted preferred shareholders the right to veto "class rights"

\footnotetext{
${ }^{15}$ While the exact wording of the veto provision differs between the standard corporate charter and the 2001 version of the law (the supermajority threshold is 66.7 percent in the former and 75 percent in the latter case), the essential common feature of both is the requirement of separate voting of preferred shareholders, which is an important check on potentially harmful "class rights" changes.

16 The prime example is the reduction in the dividend rights of preferred shareholders by discarding the 10 percent dividend rule from the charter. The list of companies that followed this path include Tyumenneftegaz and Yaroslavnefteorgsintez which replaced the 10 percent threshold with the 1 percent threshold, Izhora Works and Khantymansiyskokrtelekom, which introduced a fixed dividend equal to 12 and 10 percent of the face value of their preferred shares, respectively, as well as Baltica Brewery which calculates dividends on preferred shares using the Sberbank (Savings Bank) interest rate. Besides such immediate changes in the dividend rights, expropriation also occurred through share swaps during mergers or through arbitrary interpretation of the term "net profit" on which the dividend on preferred shares was functionally dependent while the dividend on common shares was not. Partly in response to the unfair treatment of preferred shareholders, the definition of accounting profits was tightened by Russian regulators in the early 2000s. See also the discussion in Goetzmann et al. (2002).
} 
changes and the other one that did not provide such a right. This particular feature of the population of dual class stock firms suggests the use of the difference-in-difference (DID) estimator for evaluating the effect of the 2001 statutory change, which made the veto right of preferred shareholders a mandatory rule. Methodologically, our approach is similar to that in Dharmapala and Khanna (2008) as well as in Black and Kim (2008).

The DID estimator is a commonly used empirical estimation technique in program evaluation studies. It estimates the causal effect of an experiment (such as a policy change) as the average change in the outcome in the treatment group minus the average change in the control group over the course of the experiment. An important virtue of the DID estimator is that it remains consistent even if treatment is correlated with the initial level of outcome before the experiment. The standard formulation of the DID estimator (assuming two time periods, one pre- and one post-treatment) as follows:

$$
Y_{i t}=\beta_{0}+\beta_{1}\left(G_{i} T_{t}\right)+\beta_{2} G_{i}+\beta_{3} T_{t}+\varepsilon_{i t}
$$

where $Y_{i t}$ is an outcome variable, variable $G_{i}$ is a treatment group dummy which equals 1 if an entity was affected by the experiment (policy change) and 0 otherwise, $T_{t}$ is a time dummy that equals 1 in the post-treatment period, $G_{i} T_{t}$ is the interaction of the treatment group dummy and the time dummy, and $\varepsilon_{i t}$ is a random disturbance. Subscripts $i$ and $t$ index firms and time respectively, with $t$ taking two values, 0 and 1 , for the pre- and post-treatment periods, respectively. The parameter of interest is $\beta_{1}$, which captures the average change in the outcome due to the treatment.

The DID estimator has particularly nice properties in the case of controlled experiments, where random receipt of the treatment can be ensured. In the case of quasi- or natural experiments, such as the one considered in this paper, empirical analysis relies on the exogenous variation generated by a policy change, assuming "as if” randomization (Meyer 1995). The latter cannot be tested and generally has to be defended using expert knowledge and judgment.

The critical assumptions for the DID estimator that can be tested are that of (a) common time effects across the treatment and control groups (parallel trend) and of (b) stable composition of both the treatment and control groups before and after the policy intervention. The former assumption states that the average difference in the outcome variable between the treatment and control groups would have remained constant in the absence of treatment. It can be assessed in the presence of several pre-treatment observations for the firms sampled. The 
latter assumption is crucial when the estimator is applied to repeated cross-sectional data rather than to panel data.

When perfect randomization does not hold and the probability of being in the treatment group depends on observable characteristics of firms that potentially influence the outcome variable, consistency of the DID estimator requires inclusion of these characteristics in the regression model as control variables. In such a case of conditional randomization, the baseline model (1) transforms into:

$$
Y_{i t}=\beta_{0}+\beta_{1}\left(G_{i} T_{t}\right)+\beta_{2} G_{i}+\beta_{3} T_{t}+\boldsymbol{X}_{i t} \gamma+\varepsilon_{i t}
$$

where $\boldsymbol{X}_{i t}$ is a vector of firm-level control variables and the other notations are the same as in (1). Extending model (1) to model (2) can also be motivated by efficiency reasons: variables in vector $\boldsymbol{X}_{i t}$ can measure factors that account for a part of the variation in the voting premium not attributable to the treatment itself.

We use both the most parsimonious version of the DID estimator (1) and the extended version (2) to infer about the effect of the 2001 change in corporate law on the value of preferred shares in Russia. In both (1) and (2), the treatment group dummy, $G_{i}$, takes the value of 1 if a company did not have the veto power of preferred shareholders in its charter by 2001 and 0 otherwise. The dependent variable, $V P_{i t}$, is conventionally defined as the difference between the price of common shares $\left(P_{C S h}\right)$ and the price of preferred shares $\left(P_{P S h}\right)$ divided by the price of preferred shares:

$$
V P=\frac{P_{C S h}-P_{P S h}}{P_{P S h}}
$$

This measure is known as "voting premium" in the corporate governance literature. Higher values of the dependent variable thus indicate more substantial undervaluation of preferred shares relative to common ones. Such a dependent variable has two virtues. First, the voting premium is a highly relevant indicator for assessing the effectiveness of investor protection. Indeed, the premium is directly related to the magnitude of private benefits of control (Dyck and Zingales 2004) and to the risk of expropriation of non-voting shareholders (Goetzmann et al. 2002), while the purpose of legal protection is to make the expropriation technology less efficient (La Porta et al. 2000). ${ }^{17}$ Second, the use of a relative measure that is based on two

\footnotetext{
${ }^{17}$ Interestingly, this important link between investor protection and private benefits of control has rarely been examined in the empirical literature, most likely because of the difficulties associated with measurement of control benefits. Modigliani and Perotti (1997) as well as Nenova (2006) are among the few exceptions in this regard.
} 
price observations from the same company is similar to additional differencing in that it helps eliminate idiosyncratic characteristics of firms. This is true to the extent that these characteristics affect the value of both classes of shares in a similar way. Industry- or firmlevel productivity shocks are possible examples.

The covariates in vector $\boldsymbol{X}_{i t}$ are chosen based on the analyses of the voting premium in Zingales (1995), Neumann (2003) and Muravyev (2009). ${ }^{18}$ They include the Shapley value (which is a proxy for the probability of a control fight), measures of liquidity of the two classes of stock, a measure of the difference in dividends, as well as several other covariates, such as a dummy for the issue of American Depository Receipts (ADR), that have been found important in previous studies. For example, a measure of liquidity is essential because higher liquidity ceteris paribus contributes to higher prices of shares (Stoll and Whaley 1983; Amihud and Mendelson 1986) while the importance of cross-listings in the US stock market by issuing ADR is shown in Doidge (2004). Importantly, vector $\boldsymbol{X}_{i t}$ contains variables that reflect specific characteristics of preferred stock in Russia, such as the 10 percent dividend rule and temporary enfranchisement, which may vary over time and across firms.

Besides the baseline OLS specifications (1) and (2), we consider two additional variants of the DID estimator. One is a version of models (1) and (2) with firm fixed effects applied to a panel subset of the data. ${ }^{19}$ This modification maintains stable composition of the treatment and control groups. By controlling for time-invariant unobserved characteristics of firms, it also ensures consistency of regression estimates. We also look at the effect of the policy change at the median by using the quantile (median) regression. This mitigates a possible impact of influential observations/outliers in the data on regression estimates. ${ }^{20}$ Both of these modifications provide important robustness checks for the baseline results.

The econometric model presented above is not the only possible mode of empirical analysis in the present setup. Event studies are a popular alternative strategy used in financial economics to investigate the effect of unanticipated events and policy interventions (MacKinlay 1997; Bhagat and Romano 2001). Two particular problems associated with this latter strategy prevent, however, its use in the present study. First and foremost, event studies are very sensitive to the choice of the right event date and appropriate event windows. Such a choice is an extremely difficult task in the case being considered: the statutory change

\footnotetext{
18 There are three major determinants of the voting premium in the influential model developed by Zingales (1994, 1995): the relative size of the private benefits of control, the likelihood of a control contest over the company, and the fraction of voting stock in its equity.

${ }^{19}$ We do not use the DID estimator with firm fixed effects as the benchmark approach because it results in the loss of more than 20 percent of the observations, as will be shown in the next section that describes the data.

${ }^{20}$ The median (quantile) regression offers two main advantages compared with OLS: higher robustness against outliers and better consistency performance under weaker stochastic assumptions (Koenker and Hallock 2001).
} 
resulting in the second version of the company law was debated over a long period, and it was even rejected twice by the upper chamber of the parliament (see Appendix 2 for details). More importantly, the statutory change, which was finally approved and signed by the president in August 2001, took effect only in January 2002. Thus, neither the exact timing of the event nor specific event windows can be unambiguously defined. Second, the event study methodology is applicable when stocks are actively traded in the market so that there are continuous time series on share trade. This is obviously not the case in Russia. As noted by Goriaev and Zabotkin (2006), out of 350 stocks listed in the RTS, which is the largest stock exchange of Russia in terms of coverage, only a couple dozen were more or less regularly traded in the early 2000s. For many companies, no transactions were observed during consecutive days, weeks or even months. ${ }^{21}$ The last observation is a natural transition point to the next section that describes the data.

\section{Data and sample}

Our analysis is based on a novel hand-collected dataset of traded Russian companies that had dual class shares around the enactment of the 2001 change in corporate law. The sample embraces all companies whose common and preferred shares were traded in the RTS Stock Exchange in 2000-2002. ${ }^{22}$ The only exceptions are firms with convertible preferred shares and those with a fixed preferred dividend that is not related to the dividend on common stock. ${ }^{23} \mathrm{~A}$ total of nine such cases were excluded. The choice of RTS (and not MICEX or any other stock exchange) is motivated by the wider coverage of RTS, with more than 100 dual class stock companies listed there as early as the late 1990 s. $^{24}$

The mode of share price data collection was shaped by the two issues discussed above in the context of the event study analysis: uncertainty about the exact date of the event and, more importantly, infrequent trading of Russian stocks. The unavailability of share price data during consecutive days, weeks or even months effectively rules out the approach of splitting the sample around the key dates of the legislative process: the date the new law was approved

\footnotetext{
${ }^{21}$ Dharmapala and Khanna (2008) resort to the same arguments in motivating their choice of the DID approach rather than the event study method, in the analysis of India's stock market.

${ }^{22}$ In 2001, there were about 150 companies with dual class shares listed in RTS. However, in any quarter of 2001, the number of companies with reported transactions involving both types of stock was less than half of that. In the emerging stock market of Russia, "being listed" was not always synonymous to "being traded".

${ }^{23}$ Convertibility of preferred shares virtually implies no voting premium (Muravyev 2009) and the respective companies can hardly be classified into either the treatment or control groups. As regards fixed dividend preferred shares, they are in fact close to corporate bonds, which promise investors a stream of fixed payments, and may not be easily compared with common shares.

24 The choice of a particular exchange has major implications for the measurement of liquidity, especially when the latter is based on trade volumes data. The implications for the measurement of stock prices are less important as cross-market differences in prices are being consistently eliminated by arbitrageurs.
} 
by the parliament (20 July 2001), the date it was signed by the president (7 August 2001), or the date it entered into force (1 January 2002).

We illustrate this complication and possible solutions to it in Figure 1, using share trade data on two companies, one from the treatment group (Krasnodar region telecom, KUBN) and the other one from the control group (Moscow region telecom, ESMO). The companies chosen are fairly similar in terms of their basic characteristics, such as sectoral affiliation, size, and ownership. They also belong to the group of relatively liquid firms (by standards of the Russian stock market of the early 2000s). ${ }^{25}$ Chart A of Figure 1 shows the voting premium as calculated based on average daily prices of common and preferred shares from the same trading days. In any particular trading day, an observation is non-missing only if there was at least one transaction with common shares and at least one transaction with preferred shares. The number of missing data points is remarkable under this most straightforward approach. Chart B depicts the voting premium in the two companies calculated using average daily prices of common and preferred shares from the nearest trading days, rather than from the same trading days as in Chart A. More specifically, for each day with recorded transactions of preferred shares, we find a matching common stock transaction from the same or nearest trading day. The density of data improves considerably compared with Chart A. Chart $\mathrm{C}$ shows the same time series based on the 30-day moving average of common and preferred share prices. Again, the density rises substantially compared with the two previous charts. Next, Chart D depicts the case when the voting premium is calculated using not actual, but rather imputed daily share prices based on the average of ask and bid quotations in the stock market. Finally, Chart E combines the approaches used in constructing Chart $\mathrm{C}$ and Chart D: the voting premium is based on the 30-day moving average of daily share prices imputed from ask and bid quotations. The last chart has the highest density of data and is the best in visualizing the trend in the voting premium.

As the five charts suggest, roughly until the mid-2001, the voting premium in the treatment group company (KUBN) was higher than in the control group company (ESMO). Starting in mid-2001, the situation reverses and the treatment group company exhibits the same or even lower levels of the premium. The observed pattern is broadly consistent with the hypothesis of the positive effect of the 2001 statutory change on the value of preferred shares. The time series also provide a tip, albeit very vague, about the timing of the event. Chart A suggests a dramatic reduction of the voting premium in the treatment group company

\footnotetext{
${ }^{25}$ Common and preferred shares of ESMO were traded, respectively, during 72 and 42 trading sessions out of the total of 248 sessions in 2000. The respective numbers for KUBN are 107 and 49 . Note that preferred shares were traded much less frequently than common ones.
} 
(KUBN) between June 19 and September 26, the only two dates in mid-2001 with simultaneous trading of common and preferred shares. This pattern is largely confirmed in Charts B, C, D, and E of Figure 1.

The limitations in the data stemming from infrequent trading and ambiguous timing of the event are addressed in this paper in the following way. First, in order to increase the number of observations, we choose relatively long pre- and post-treatment periods, and also compute period averages of stock prices. Such strategies are not uncommon in empirical investigations of emerging markets. For example, Chung and Wie (2005) and Black et al. (2006) rely on quarterly average share prices in their studies of the contemporary Chinese and Russian stock markets. In the case of India's stock market, Dharmapala and Khanna (2008) even employ the 365-day average. Similarly, Hilt (2008) uses quarterly averages in his analysis of the 19th century US stock market, which at that time was also characterized by infrequent trading and low liquidity. Second, we specify a considerable interval between the pre- and post-treatment periods so that it supposedly covers the "event date". The benchmark dataset is constructed using share trade data from early 2001 (before the final legislative round leading to the adoption of the law) and early 2002 (after the law took effect).

More specifically, we construct the benchmark dataset based on the method employed in drawing Chart B of Figure 1. In both 2001 and 2002, the voting premium is calculated using actual prices observed on April 1 or the closest trading day in the case of no registered transactions with either common or preferred shares on 1 April. Importantly, in collecting share price data we restrict ourselves to the sixth month interval spanning from January to June each year. The approach chosen is obviously imperfect, but viable. For 75 percent of observations, the difference between the dates of common and preferred share trades does not exceed 7 days.

In addition, the following two alternatives are considered. First, we take a different pre-treatment period, with share price data collected around 1 April 2000 instead of 1 April 2001. Such an expansion of the interval between the pre- and post-treatment periods improves the chance that the interval contains the true event date. Second, we employ averages of prices imputed from ask and bid quotations for May 2001 and January 2002, the first pair of pre- and post-treatment periods, as well as for June 2001 and September 2001, the second pair of preand post-treatment periods.

The RTS data on share trade, collected along the lines described above, were supplemented with information on ownership, dividends, and characteristics of shares from companies’ quarterly reports to the Federal Financial Market Service (FFMS). Particular care 
was taken of data concerning the presence of the veto power in corporate charters before 2002, which were crucial for distinguishing between the treatment and control groups. For that purpose, we checked not only company quarterly reports, but also share issue prospects and corporate charters. All data were obtained from publicly available sources, such as the RTS website (http://www.rts.ru), the FFMS web-site (http://www.openinfo.ffms.ru), as well as the websites of the sampled companies.

Constructed along these lines, the benchmark sample includes 178 observations (82 in 2001 and 96 in 2002). Of these, 146 observations (corresponding to 73 firms) form a balanced panel. Table 1 provides a summary of the observable characteristics of companies from the treatment and control groups measured in the first quarter of $2001 .^{26}$ These include characteristics that were found important in previous analyses of dual class shares, such as Zingales (1994). Definitions of the variables are provided in Table 2.

The descriptive statistics in Table 1 show a very high (by international standards) magnitude of the voting premium in 2001, over 100 percent in both the treatment and control groups. This is consistent with previous studies of Russia and the view of the country as a "Wild West of corporate control" (Goetzmann et al. 2003). Table 1 also shows that the two groups of companies are similar in many respects, such as dividend policies and the issue of American Depository Receipts (ADR). However, there are some dissimilarities. In particular, more than two-thirds of firms in the control group belong to power utilities while the treatment group is grossly dominated by telecoms. This is in line with the discussion in Section 2 of changes in corporate charters in the mid-1990s. Importantly, simple probit regressions of the probability of being in the treatment group (not shown) reveal that the sectoral dummies are the only factors that are persistently significant across specifications and years. ${ }^{27}$ Overall, there is considerable overlap in the characteristics of affected and unaffected firms.

Table 3 reports changes in the voting premium in the control and treatment groups of the benchmark sample in 2000-2002. These raw data indicate a higher premium in the treatment group compared with the control group in all three years and a steady decline in the

\footnotetext{
${ }^{26}$ The small number of observations both necessitates and makes possible a careful check of outliers in the data. We have examined 10 percent of observations in the tails of the distribution of the voting premium (which ranges from -0.71 to 6.16 in the benchmark dataset) as candidate outliers. About two-thirds of these observations are from low liquidity companies, and the abnormally high/low values of the voting premium are typically driven by unusual (and, possibly, manipulated) transactions, which can be defined as those with transaction prices outside the daily bid-ask interval. In such instances, we replace the anomalous price observations with the nearest ones in terms of date of trade. It turns out, however, that such a careful cleaning is nearly equivalent to a brute force approach involving winsorizing of 5 percent of the observations in the tails of the distribution, both with and without conditioning on the year of observation and treatment status.

${ }^{27}$ This correlation between being in the treatment group and sectoral affiliation suggests that sectoral controls need to be included in the regression equation.
} 
premium between 2000 and 2001, as well as between 2001 and 2002, in both groups. Interestingly, the decline in the premium in 2000-2001 is fairly similar among the two groups: 66 percentage points in the control group and 64 percentage points in the treatment group. This provides support to the parallel trend assumption that underlies the DID estimator: the trend in 2000-2001 was the same for both groups and would probably have stayed the same in 2001-2002 in the absence of the treatment. The decline in the voting premium in 2001-2002 is, however, much stronger in the treatment group. By 2002, the difference between the groups is mere 11 percentage points, while it is 41 percentage points in 2001 and 38 percentage points in 2000. These basic statistics are consistent with the hypothesis that the 2001 statutory change had a positive impact on the value of preferred shares. In the next section, we test this hypothesis using the multivariate regression framework as described in Section 3.

\section{Empirical analysis}

\subsection{Baseline results}

Table 4 shows the baseline regression results obtained by applying the DID estimator to the 2001-2002 benchmark sample of 178 observations. Four sets of estimates, which differ in terms of covariates used, are reported in the table. Column 1 presents results from the most parsimonious DID specification without any additional controls. These estimates suggest a steeper decline of the voting premium in the treatment group compared with the control group between 2001 and 2002. The difference amounts to 31 percentage points (see the coefficient

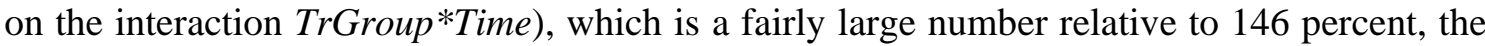
sample average premium in 2001. The results also show a considerable difference in the baseline level of the voting premium between the treatment and control groups, about 47 percentage points. Also notable is the time trend, suggesting a decline of the voting premium by about 38 percentage points between 2001 and 2002.

The regression reported in Column 2 differs from that in Column 1 by the inclusion of sectoral dummies. As discussed above, they are highly correlated with the likelihood of being in the treatment group; therefore, omitting them in the regression model is potentially fraught with inconsistent estimates. The results shown in Column 2, however, do not suggest a substantial role of these sectoral variables. Indeed, the respective coefficients are statistically insignificant both separately and jointly in the F-test (not reported). Moreover, the results are very similar to those from the most parsimonious specification in Column 1. 
The specification in Column 3 expands the set of controls even further, by adding covariates characterizing liquidity of common and preferred stocks as well as those measuring deviations of the date of trade from the "benchmark" date of trade, which is April 1. The latter controls are intended to capture the upward trend in the Russian stock market in the early 2000s. This is essential because, by construction of the dataset, share price data may come from any trading day within the January-June interval, and not necessarily April 1, the benchmark date. Despite the fact that the liquidity variables enter the regression model statistically significantly, the main coefficient of interest stays virtually the same as before, close to 30 percentage points. Little is changed when additional firm-level covariates, such as the Shapley value and the dummy for the issue of ADR, are introduced in the econometric model. These results are shown in Column 4. While most of the additional covariates fail to achieve statistical significance, they usually have the expected signs. For example, the premium appears to fall with higher liquidity of preferred stocks, as the coefficient on the respective variable suggests. There is also some evidence that the premium is smaller in companies that pay higher dividends on preferred shares, though the coefficients on variables DDividend and Dividend10 are statistically insignificant in the reported specification. Overall, the baseline regression results can be interpreted as indicating an economically and statistically significant effect of reintroducing the veto power of preferred shareholders in the company law. ${ }^{28}$

Table 5 shows results from additional specifications, providing important robustness checks for the baseline estimates. First, Column 1 and Column 2 show results from the models with firm fixed effects estimated on the panel sub-sample of the original data. The number of observations drops to 146 out of the total of 178 in the full sample. In the most parsimonious DID specification with firm fixed effects reported in Column 1, the coefficient on the variable of interest declines to 27 percentage points, but it remains statistically significant at the 10 percent level. The regression in Column 2 that contains the full set of controls, including firm-level covariates, confirms the previous findings. Some of the additional regressors turn out statistically significant in this specification. As may be expected, the coefficient on the Shapley value is positive (suggesting higher voting premia in companies with higher probability of control contests). Quite expectedly, the coefficient on the variable measuring the difference in dividends is negative. The premium is smaller the larger the (positive) difference between the preferred share dividend and the common share

\footnotetext{
${ }^{28}$ These and other results change little if alternative procedures of data cleaning are applied. For example, Appendix 3 shows regression results obtained using the same specifications and winsorized data on voting premium (5 percent in each tail of the distribution).
} 
dividend. These results are in line with international studies of the voting premium, such as Zingales (1994) and Nenova (2003).

Column 3 and Column 4 of Table 5 show estimation results from the models that combine the DID estimator with the quantile (median) regression. Column 3 reports estimates from the most parsimonious specification augmented with sectoral dummies while Column 4 presents results obtained with the full set of additional covariates. In both cases, the coefficient of interest maintains the magnitude found in the previous regressions, about 30 percentage points, albeit marginally statistically insignificant in the regression in Column 4.

Finally, Column 5 and Column 6 report estimation results from the 2000-2002 sample, in which the 2000 data replace those from 2001. By expanding the interval between the preand post-treatment periods, we conduct an additional test of the stability of the baseline estimates. The results generally confirm the previously discovered pattern: in the treatment group, the premium declines by about 30 percentage points more than in the control group. $\mathrm{A}$ number of other regression coefficients are worth commenting on. First, higher liquidity of common stocks turns out to drive the voting premium up. Second, the presence of the 10 percent dividend rule in the company's charter is associated with the reduction of the premium by about 49 percentage points. Third, the issue of ADR also implies a lower discount on preferred shares. All these results are expected and consistent with previous studies, for example, Doidge (2004) and Neumann (2003).

Table 6 shows results from additional robustness checks in which we use two different pre- and post-treatment periods (May 2001 versus January 2002 as well as June 2001 versus September 2001) and calculate the voting premium based on share prices imputed from ask and bid quotations, as in Chart $\mathrm{E}$ of Figure 1. In particular, in the first step, the average of ask and bid prices is computed for each stock and each date. These estimates are then averaged over time for each stock. In the final step, the voting premium is computed using the standard formula (3). Columns 1 and 2 show results for the first pair of pre- and post-treatment periods. $^{29}$ Because of the use of averages, variables TrdateC and TrdateP, which measure deviations of the dates of trade from the benchmark date (1 April each year), are excluded. The regression results show a negative and statistically significant effect of the 2001 statutory change on the voting premium, with magnitudes fairly close to those found in the benchmark estimations. Columns 3 and 4 present regression results for the second pair of pre- and posttreatment periods (June 2001 and September 2001, respectively). They also suggest a significant effect of the change in law on the value of preferred shares. The magnitude of the

\footnotetext{
${ }^{29}$ In this exercise, we winsorize 10 percent of the observations of the voting premium (5 percent in each tail of the distribution).
} 
effect (and its statistical significance) in these regressions is somewhat smaller than in the previous estimations. A plausible explanation for this fact is that the effect of the statutory change was not fully realized by September 2001 because the new version of the law took effect in January 2002 only.

The various specifications considered produce similar results: the decline in the voting premium attributable to the statutory change is about 30 percentage points or 20 percent relative to the sample average premium in 2001. How large is this effect? To answer this question, it is worth noting that the voting premium in Russia was continuously falling from about 200\% in 2000 to mere 45\% in 2005 (Muravyev 2009). Between 2002 and 2005, when the veto power of preferred shareholders already applied to all firms, there was a two-fold reduction in the premium. Even between 2001 and 2002, the period of the treatment localization, the general (that is, not related to the treatment) decline of the premium exceeded the decline attributable to the treatment (40 versus 30 percentage points, as indicated in Table 4). This suggests that the statutory change considered was an important, but not a major development in Russian corporate governance in the early 2000s.

\subsection{Further issues}

\subsubsection{The assumption of "as if" randomization}

Similarly to other evaluation studies involving quasi- rather than true experiments, our analysis rests on the (non-testable) assumption of exogenous policy intervention and of no self-selection of firms into the treatment and control groups. But is it likely to hold in the present setup?

The first thing to be noted in this connection is that sorting of dual class firms into the treatment and control groups around the time of the 2001 law change is not an issue in our study. This stems from the nature of the policy intervention analyzed, which implied convergence rather than divergence among affected and unaffected firms. If there was a sorting, it could only occur in the mid-1990s, when dual-class firms faced the challenge of bringing their charters in conformity with the newly adopted company law. Essentially, the 2001 change in law implied a reversal of the (initial) treatment that took place in the mid1990s. Thus, the issue is whether firms' decisions concerning the veto right in the mid-1990s were made in anticipation of their effect on stock and company valuation, were influenced by corporate governance factors potentially affecting the voting premium, were shaped by other factors not related to the voting premium, or were made completely at random. 
We believe that concerns about stock and company value were unlikely to shape firms' decisions about keeping the veto right in their charters simply because an organized stock market did not exist in Russia in the mid-1990s. As a consequence, "firm value" and "stock value" were largely elusive concepts. This is particularly true of preferred stocks, which started appearing in the RTS listing in September 1996 only. On the other extreme, it is also hard to argue that the process of introducing changes in the charters was completely random.

As indicated in the example of government-controlled telecoms and power utilities presented in Section 2, the single most important corporate governance factor - ownership was not decisive in the process of corporate charter amendments. However, the fact that many companies simply copied entire paragraphs/articles from the new law into their corporate charters (instead of a careful and minimalist adaptation of the charters to the new requirements) suggests a role played by the lack of firms' experience in and familiarity with corporate law and corporate governance. This hypothesis, which was introduced in Section 2, finds considerable support in company-level data. Most importantly, the probability to retain the veto right in the charters turns out to be related to the size of firms and to the time of their privatization. First, firms that were corporatized and offered for privatization earlier were more likely to keep the veto rule in their charters. A plausible explanation for this pattern is that such firms had longer exposure to corporate law and therefore were better prepared to a careful revision of the charters compared with recently privatized firms. The sectoral differences, in particular between the telecoms and power utilities, are also consistent with this story: privatization of power utilities started on average nine months earlier than that of telecoms, and this difference is statistically significant at the 1 percent level. ${ }^{30}$ Second, the probability of abolishing the veto right was negatively related to company size. A comprehensive revision of the charter may simply have been costly for smaller firms that had smaller legal departments. As a result, in the mid-1990s, they ended up adopting the copypaste approach. Appendix 4 shows several probit regressions of the probability of being in the treatment group, which we estimate using scarce company-level data from 1996. It remains to note that variables such as the time of privatization and company size would be helpful in a more sophisticated econometric approach involving instrumenting for the treatment, but the

\footnotetext{
${ }^{30}$ A related explanation involves the fact that in earlier privatized firms, the redistribution of preferred shares from employees (original small owners) to outside investors (typically blockholders) was at a more advanced stage by 1996. This implied that such concentrated, and therefore less subject to the free-rider problem, investors into preferred stock were better able to oversee charter changes in earlier privatized companies.
} 
extremely small number of observations makes this research strategy non-viable in the present study. ${ }^{31}$

Another important piece of evidence supporting the assumption of "as if" randomization comes from comparing corporate governance scores of firms in the treatment and control groups. For this purpose we use the corporate governance rating produced by the Moscow-based Institute of Corporate Law and Corporate Governance (http://www.iclg.ru). In the early 2000s, the institute acquired small minority stakes in several dozen Russian blue chips in order to collect and evaluate information provided by these companies to their shareholders. These data, combined with publicly available information about the firms, were transformed into a single score characterizing each company's corporate governance practices. The score varied from 0 to 100 , where the maximum value corresponded to an ideal reference firm. This rating has been used in a number of previous studies of the Russian stock market, including Black et al. (2006).

The scores from the end of 2001 are available for 40 companies only, of which 25 are dual-class stock firms. Among these 25 companies, 17 are from the treatment group and 8 are from the control group. The variation in the corporate governance scores of these firms is substantial: the range is from 40.1 to 64.8 . However, the average scores in the treatment and control groups turn out to be very similar, 51.6 versus 53.2, respectively. The two-tailed test for the equality of means does not reject the null at the conventional significance levels. Despite the small number of observations, this comparison does provide important support to the idea that the treatment and control group companies were not systematically different from each other in terms of corporate governance. ${ }^{32}$ In sum, the available evidence runs contrary to the hypothesis of self-selection of Russian dial class firms into the treatment and control groups.

\subsubsection{The effect of the change in law on the value of firms}

So far our discussion has focused on the effect of the change in law on the relative value of preferred shares. While there are clear virtues in using the voting premium for measuring the effectiveness of the legal change, the reader may still wonder whether this change implied an increase in the overall value of firms, as opposed to a simple transfer of value from common

\footnotetext{
${ }^{31}$ Such an exercise would relate a change in the voting premium between 2001 and 2002 to the treatment dummy instrumented by the time of privatization and firm size. However, the available 73 observations of changes in the voting premium are definitely not enough for an IV analysis, which is bound to be inefficient.

32 This also suggests that the results are not driven by other changes in shareholder protection introduced in the 2001 law: since companies from the treatment and control groups were fairly similar in terms of corporate governance, these other changes should not have differential effects between the two groups.
} 
shareholders to preferred shareholders. To address this issue, we use the familiar econometric framework to estimate the effects of the change in law on the value of firms. The latter is associated with Tobin's Q, a conventional measure, which we proxy by the ratio of the market value of the firm's equity to the book value of its equity. ${ }^{33}$ Descriptive statistics of the new dependent variable in 2001 is shown in Table 1.

Table 7 shows results from estimating six regressions with Tobin's Q as dependent variable in which we use the same controls as in the analysis of voting premium. The regression results reported in the odd columns correspond to the most parsimonious DID specification augmented with sectoral dummies. The even columns show results for the specification with the full set of controls. Columns 1 and 2 report OLS results, Columns 3 and 4 the results from the fixed effects regressions and Columns 5 and 6 the quantile regressions. The estimates obtained in all these regressions are fairly similar with respect to the variable of interest: in 2001-2002, the increase in the value of companies from the treatment group was on average higher than that in the control group.

A remarkable feature of the results reported in Table 7 is the high statistical and economic significance of the sectoral dummies in comparison with the voting premium regressions, where these dummies were mostly insignificant. This supports the idea that the dependent variable in our main regressions, the voting premium, indeed helps eliminate the effect of idiosyncratic characteristics of firms. ${ }^{34}$ It should also be mentioned that in contrast to the results for the voting premium, our results for Tobin's Q are quantitatively rather sensitive to the level of aggregation of industries: introducing more sectoral dummies in the regressions substantially reduces the magnitude of the coefficient on the main variable of interest, TrGroup*Time. Nevertheless the coefficient always stays positive and remains statistically significant in several specifications. ${ }^{35}$ Overall, one can conclude that the 2001 change in law did not imply a mere transfer of value from common to preferred shareholders, but rather led to an increase in company value.

\footnotetext{
${ }^{33}$ In order to calculate Tobin's Q, we use share prices from the benchmark approach (around 1 April 2001 and 1 April 2002) and book values of equity as of 1 January 2001 and 1 January 2002, available from the annual financial reports of the sampled companies.

${ }^{34}$ To give an example, a substantial increase in oil prices is likely to positively affect the values of both common and preferred shares of the oil sector companies. As the computation of the voting premium uses the difference between the prices of the two classes of stock, much of the effect of increased oil prices is differenced away. This is not the case with Tobin's Q. An oil price rally would raise Tobin's Q of companies belonging to the oil extraction industry relative to firms from other sectors.

${ }^{35}$ These additional results with disaggregated sectoral controls are not shown, but available on request.
} 


\section{Conclusion}

The move from a centrally planned economy towards a market-based system in Russia involved a great deal of experimentation, including with law, much of which had to be created from scratch. This is particularly true of corporate law, which was irrelevant and did not exist in the country during most of the 20th century. The difficulties involved in the process of creating new legal institutions have been well-described, including by those directly involved in the process in the 1990s (e.g., Black and Kraakman 1996).

In this paper we use a quasi-experimental framework provided by changes in corporate law in post-communist Russia to study the effect of improved shareholder protection on the value of shares. The legal change analyzed involves the empowerment of preferred (non-voting) shareholders to veto unfavorable changes in their class rights. Employing the difference-in-difference estimator, we find a statistically and economically significant effect of improved protection of preferred shareholders on the value of preferred shares. The latter is measured relative to common shares, using the voting premium approach, a measure of private benefits of control (Dyck and Zingales 2004) and shareholder expropriation (Goetzmann et al. 2002) in the corporate governance literature. We find that the voting premium in Russian dual class stock companies declined by about 30 percentage points (relative to the average of 146 percent observed in the sample in 2001) as a consequence of the statutory change. This result is robust to the inclusion in the econometric models of company-level covariates, to the use of different pre- and post-treatment periods, as well as to alternative estimation techniques. Importantly, the result does not appear to be driven by selfselection of firms into the treatment and control groups. We also present evidence that the statutory change did not imply a mere transfer of value from common to preferred shareholders, but rather led to an increase in company value.

Our paper contributes to the rapidly growing literature on investor protection by documenting a key role of law in restraining shareholder expropriation and in boosting share prices. Specifically, it highlights the importance of legal mechanisms protecting against "class rights" changes in companies with multiple classes of stock. The main value added of the paper comes from its identification strategy that allows estimation of the causal effect of legal protection. This is something that many previous studies have found extremely difficult to identify (Costa and Mello 2006). Because the paper focuses on Russia, a country which has been notoriously known for inefficient enforcement of law, its findings are useful in the debate concerning the role of formal law in the weak enforcement environment (Berglof and Claessens 2004). The present analysis suggests that law on the books may work even when 
law enforcement is far from perfect. Finally, the paper contributes to the small but growing literature on corporate law and corporate governance in the emerging economy of Russia. 


\section{References}

Adams, Renée B. and Daniel Ferreira (2008) One Share, One Vote: The Empirical Evidence. Review of Finance, 12: 51-91.

Amihud, Yakov, and Mendelson, Haim (1986) Asset Pricing and the Bid-Ask Spread. Journal of Financial Economics, 17(2): 223-249.

Bebchuk, Lucian A., Alma Cohen, and Allen Ferrell (2004) What Matters in Corporate Governance? Working paper, Harvard Law School and NBER.

Berglof, Erik, and Stijn Claesseus (2004) Corporate Governance and Enforcement. World Bank Policy Research Working Paper No. 3409, World Bank.

Bergman, Nittai K. and Nicolaievsky, Daniel (2007) Investor Protection and the Coasian View. Journal of Financial Economics, 84(3): 738-771.

Bhagat, Sanjai and Roberta Romano (2002) Event Studies and the Law: Part II: Empirical Studies of Corporate Law. American Law and Economics Review, 4(2): 380-423.

Black, Bernard S. (1990) Is Corporate Law Trivial?: A Political and Economic Analysis. Northwestern University Law Review 84: 542-597.

Black, Bernard S. and Woochan Kim (2008) The Effect of Board Structure on Firm Value: A Multiple Identification Strategies Approach Using Korean Data. Law and Economics Working Paper No. 89, University of Texas School of Law.

Black, Bernard S. and Rainer Kraakman (1996) A Self Enforcing Model of Corporate Law. Harvard Law Review, 109: 1911-1982.

Black, Bernard S., Rainer Kraakman, and Anna Tarassova (2000) Russian Privatization and Corporate Governance: What Went Wrong? Stanford Law Review, 52: 1731-1808.

Black, Bernard S., Hasung Jang, and Woochan Kim (2006) Does Corporate Governance Predict Firms' Market Values? Evidence from Korea. Journal of Law, Economics and Organization, 22(2): 366-413.

Black, Bernard S., Love, Inessa, and Rachinsky, Andrei (2006) Corporate Governance Indices and Firms' Market Values: Time Series Evidence from Russia. Emerging Markets Review, 7(4):361-379.

Black, Bernard S. and Khanna, Vikramaditya S. (2007) Can Corporate Governance Reforms Increase Firm Market Values? Event Study Evidence from India. Journal of Empirical Legal Studies, 4(4): 749-796.

Blasi, Joseph, Kroumova, Maya, and Douglas Kruse (1997), Kremlin Capitalism: The Privatization of the Russian Economy, Ithaca, NY and London: Cornell University Press.

Burkart, Mike and Samuel Lee (2008) One Share - One Vote: The Theory. Review of Finance, 12(1): 1-49.

Bruno, Valentina and Claessens, Stijn (2007) Corporate Governance and Regulation: Can There Be Too Much of a Good Thing? CEPR Discussion Paper No. 6108, C.E.P.R. Discussion Papers.

Chhaochharia, Vidhi and Grinstein, Yaniv (2007) Corporate Governance and Firm Value: The Impact of the 2002 Governance Rules. Journal of Finance, 62(4): 1789-1825.

Chung, Shifei and Peihwang Wie (2005) The Relationship between Bid-ask Spreads and Holding Periods: The Case of Chinese A and B Shares. Global Finance Journal, 15(3):239249. 
Coase, Ronald (1960) The Problem of Social Cost. Journal of Law and Economics, 3(1):1-44.

Coffee, John C., Jr. (1989) The Mandatory/Enabling Balance in Corporate Law: An Essay on the Judicial Role. Columbia Law Review, 89: 1618-1691.

Costa, Ana Carla A. and Joao M.P. De Mello (2006) Judicial Risk and Credit Market Performance: Micro Evidence from Brazilian Payroll Loans. NBER Working Paper 12252, National Bureau of Economic Research.

Dahya, Jay and John McConnell (2007) Board Composition, Corporate Performance, and the Cadbury Committee Recommendation (Digest Summary). Journal of Financial and Quantitative Analysis, 42(3): 535-564.

Dharmapala, Dhammika and Khanna, Vikramaditya (2008) Corporate Governance, Enforcement, and Firm Value: Evidence from India. SSRN working paper.

Doidge, Craig (2004) U.S. Cross-listings and the Private Benefits of Control: Evidence from Dual Class Firms. Journal of Financial Economics, 72(3): 519-553.

Dyck, Alexander and Zingales, Luigi (2004) Private Benefits of Control: An International Comparison. Journal of Finance, 59(2): 537-600.

Dyck, Alexander, Volchkova, Natalia and Luigi Zingales (2004) The Corporate Governance Role of the Media: Evidence from Russia. Journal of Finance, 63(3): 1093-1135.

Easterbrook, Frank H., and Daniel R. Fischel (1991) The Economic Structure of Corporate Law. Cambridge, Mass.: Harvard University Press.

Goetzmann, William N., Matthew Spiegel, and Andrey Ukhov (2003) Modeling and Measuring Russian Corporate Governance: The Case of Russian Preferred Common Shares. NBER Working Paper No. 9469, NBER.

Gompers, Paul, Joy Ishii and Andrew Metrick (2003) Corporate Governance and Equity Prices. Quarterly Journal of Economics, 118: 107-155.

Goriaev, Alexei and Zabotkin, Alexei (2006) Risks of Investing in the Russian Stock Market: Lessons of the First Decade. Emerging Markets Review, 7(4): 380-397.

Grossman, Sanford and Oliver Hart (1980) Takeover Bids, the Free-rider Problem, and the Theory of the Corporation. Bell Journal of Economics, 11: 42-64.

Hare, Paul, and Muravyev, Alexander (2003) Privatization in Russia, in: D. Parker, D. Saal (eds.) "International Handbook on Privatization", Edward Elgar Publishing, Cheltenham, UK.

Harris, Milton and Raviv, Artur (1988) Corporate Control Contests and Capital Structure. Journal of Financial Economics, 20(1-2): 55-86.

Hart, Oliver (1995) Firms, Contracts, and Financial Structure. Clarendon Press, Oxford.

Hilt, Eric (2008) Wall Street's First Corporate Governance Crisis: The Conspiracy Trials of 1826. Paper presented at the University of California Davis conference "Crises and Prosperity in Comparative Economic History”, May 23-25, 2008.

Jain, Pankaj K., and Zabihollah Rezaee (2006) The Sarbanes-Oxley Act of 2002 and Capital Market Behavior: Early evidence. Contemporary Accounting Research, 23: 629-654.

Klapper, Leora F. and Love, Inessa (2004) Corporate Governance, Investor Protection, and Performance in Emerging Markets. Journal of Corporate Finance, 10(5): 703-728.

Koenker, Roger and Kevin F. Hallock (2001). Quantile Regression. Journal of Economic Perspectives, 15(4): 143-156. 
La Porta, Rafael, Florencio Lopez-de-Silanes and Andrei Shleifer (1998) Law and Finance. Journal of Political Economy, 106: 1113-1155.

La Porta, Rafael, Florencio Lopez-de-Silanes, Andrei Shleifer, and Robert Vishny (1997) Legal Determinants of External Finance. Journal of Finance, 52: 1131-1150.

La Porta, Rafael, Florencio Lopez-de-Silanes, Andrei Shleifer, and Robert Vishny (2000) Investor Protection and Corporate Governance. Journal of Financial Economics, 58: 3-29.

Li, Haidan, Morton P. K. Pincus, and Sonja O. Rego (2008) Market Reaction to Events Surrounding the Sarbanes-Oxley Act of 2002 and Earnings Management. Journal of Law and Economics, 51(1): 111-134.

Litvak, Kate (2007) The Effect of the Sarbanes-Oxley Act on non-US Companies Cross-listed in the US. Journal of Corporate Finance, 13(2-3): 195-228.

MacKinlay A. Craig (1997) Event Studies in Economics and Finance. Journal of Economic Literature, 35(1): 13-39.

Mahoney, Paul G. (1995) Mandatory Disclosure as a Solution to Agency Problems. University of Chicago Law Review, 62: 1047-1112.

Meyer, Bruce D. (1995) Natural and Quasi-Experiments in Economics, Journal of Business and Economic Statistics, 13: 151-162.

Modigliani, Franco and Enrico Perotti (1997) Protection of Minority Interest and the Development of Security Markets. Managerial and Decision Economics, 18 (7-8): 519-528

Muravyev, Alexander (2009) Dual Class Stock in Russia: Explaining a Pricing Anomaly, Emerging Markets Finance and Trade, 45(2): 39-61.

Nenova, Tatiana (2003) The Value of Corporate Voting Rights and Control: A Cross-Country Analysis. Journal of Financial Economics, 68(3): 325-351.

Nenova, Tatiana (2006) Control Values and Changes in Corporate Law in Brazil. Latin American Business Review, 6(3): 1-37.

Neumann, Robert (2003) Price Differentials between Dual-class Stocks: Voting Premium or Liquidity Discount? European Financial Management, 9(3): 315-332.

Pistor, Katharina, Martin Raiser, and Stanislaw Gelfer (2000) Law and Finance in Transition Economies. Economics of Transition, 8(2): 325-368.

Securities Market (1998) Puzzles of the Russian Preferred Shares. Securities Market, 4 (in Russian).

Stoll, Hans R. and Whaley, Robert E. (1983) Transaction Costs and the Small Firm Effect. Journal of Financial Economics, 12(1): 57-79.

Wintoki, M. Babajide (2007) Corporate Boards and Regulation: The Effect of the SarbanesOxley Act and the Exchange Listing Requirements on Firm Value. Journal of Corporate Finance, 13(2-3): 229-250.

Zhang, Ivy Xiying (2007) Economic Consequences of the Sarbanes-Oxley Act of 2002. Journal of Accounting and Economics, 44(1-2): 74-115.

Zingales, Luigi (1994) The Value of the Voting Right: A Study of the Milan Stock Exchange Experience. Review of Financial Studies, 7(1): 125-148.

Zingales, Luigi (1995) What Determines the Value of Corporate Votes? Quarterly Journal of Economics, 110(4): 1047-1073. 
Figure 1. Different approaches to calculating the voting premium.
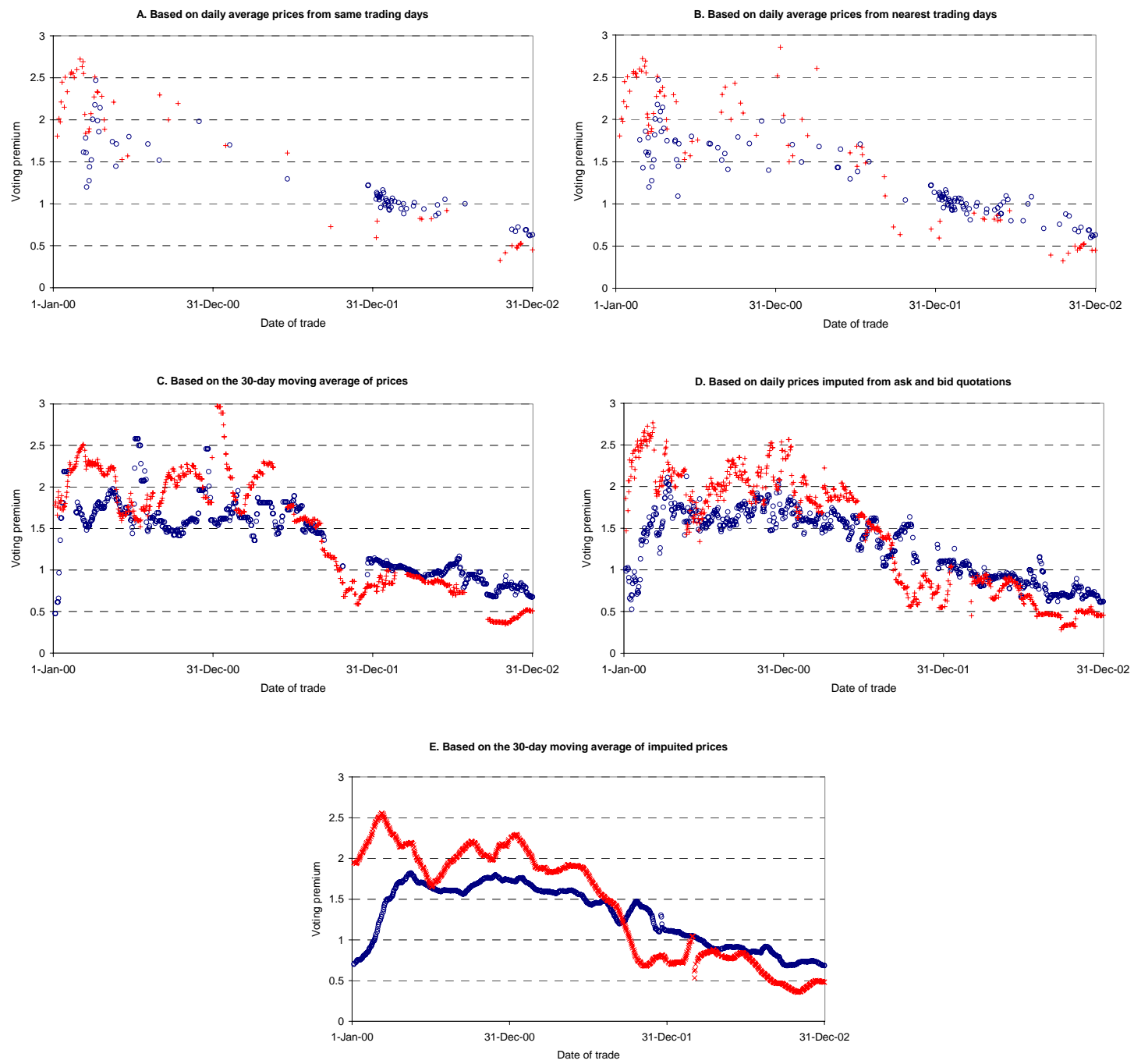

+ - Krasnodar region telecom (KUBN), treatment group $\circ$ - Moscow region telecom (ESMO), control group 
Table 1. Descriptive statistics of the treatment and control groups in 2001.

\begin{tabular}{|c|c|c|c|c|c|c|c|c|c|c|c|c|}
\hline & \multicolumn{5}{|c|}{ Control group } & \multicolumn{5}{|c|}{ Treatment group } & \multicolumn{2}{|c|}{ Mean comparison } \\
\hline & $\mu$ & $\sigma$ & $\min$ & p50 & $\max$ & $\mu$ & $\sigma$ & $\min$ & p50 & $\max$ & $\mu_{1}-\mu_{2}$ & p-value* \\
\hline VP & 1.134 & 0.612 & 0.194 & 1.037 & 2.548 & 1.608 & 0.706 & 0.154 & 1.600 & 3.437 & -0.474 & 0.005 \\
\hline Energos & 0.680 & 0.476 & 0 & 1 & 1 & 0.070 & 0.258 & 0 & 0 & 1 & 0.610 & 0.000 \\
\hline Oil\&Chemical & 0.080 & 0.277 & 0 & 0 & 1 & 0.158 & 0.368 & 0 & 0 & 1 & -0.078 & 0.347 \\
\hline Telecoms & 0.200 & 0.408 & 0 & 0 & 1 & 0.702 & 0.462 & 0 & 1 & 1 & -0.502 & 0.000 \\
\hline Others & 0.040 & 0.200 & 0 & 0 & 1 & 0.070 & 0.258 & 0 & 0 & 1 & -0.030 & 0.604 \\
\hline LiquidityC & 0.592 & 0.273 & 0.043 & 0.643 & 0.997 & 0.718 & 0.193 & 0.150 & 0.760 & 0.994 & -0.126 & 0.020 \\
\hline LiquidityP & 0.507 & 0.290 & 0.055 & 0.510 & 0.975 & 0.596 & 0.239 & 0.011 & 0.615 & 0.989 & -0.089 & 0.150 \\
\hline DateC & 13.08 & 44.412 & -82 & 9 & 86 & 11.842 & 41.631 & -75 & 0 & 82 & 1.238 & 0.904 \\
\hline DateP & 11.12 & 49.155 & -82 & 9 & 86 & 10.789 & 43.08 & -68 & 1 & 79 & 0.331 & 0.976 \\
\hline$\Phi$ & 0.044 & 0.124 & 0 & 0 & 0.475 & 0.022 & 0.075 & 0 & 0 & 0.388 & 0.022 & 0.320 \\
\hline$\pi$ & 0.796 & 0.058 & 0.750 & 0.772 & 0.952 & 0.765 & 0.040 & 0.750 & 0.750 & 0.963 & 0.031 & 0.007 \\
\hline$\Delta$ Dividend & 0.082 & 0.221 & -0.083 & 0 & 1.083 & 0.066 & 0.109 & -0.040 & 0 & 0.564 & 0.017 & 0.650 \\
\hline Dividend10 & 0.960 & 0.200 & 0 & 1 & 1 & 0.930 & 0.258 & 0 & 1 & 1 & 0.030 & 0.604 \\
\hline Enfranch & 0.160 & 0.374 & 0 & 0 & 1 & 0.070 & 0.258 & 0 & 0 & 1 & 0.090 & 0.212 \\
\hline ADR & 0.240 & 0.436 & 0 & 0 & 1 & 0.211 & 0.411 & 0 & 0 & 1 & 0.029 & 0.770 \\
\hline Tobin’s Q & 0.324 & 0.365 & 0.031 & 0.160 & 1.262 & 0.663 & 0.681 & 0.071 & 0.473 & 4.801 & -0.339 & 0.022 \\
\hline \multirow[t]{2}{*}{ Ln(Equity) } & 5.185 & 1.271 & 2.438 & 5.157 & 8.593 & 3.928 & 1.383 & 0.976 & 3.551 & 9.029 & 1.256 & 0.000 \\
\hline & $\mathrm{N}=25$ & & & & & $\mathrm{~N}=57$ & & & & & & \\
\hline
\end{tabular}

* p-value refers to the two-tailed test for the equality of means. 
Table 2. Definitions of the variables.

\begin{tabular}{|c|c|c|}
\hline Variable & Meaning & Definition \\
\hline VP & Voting premium & $\begin{array}{l}\text { Difference between the price of common shares } \\
\text { and the price of preferred shares divided by the } \\
\text { latter. }\end{array}$ \\
\hline TrGroup & Treatment group dummy & $\begin{array}{l}\text { Equals } 1 \text { if a company belongs to the treatment } \\
\text { group. }\end{array}$ \\
\hline Time & $\begin{array}{l}\text { Dummy for post-treatment } \\
\text { period }\end{array}$ & $\begin{array}{l}\text { Equals } 1 \text { for observations from post-treatment } \\
\text { periods. }\end{array}$ \\
\hline Energos, & & Sectoral dummies for power utilities, \\
\hline $\begin{array}{l}\text { Oil\&Chemical, } \\
\text { Telecoms, Others }\end{array}$ & Industry affiliations & $\begin{array}{l}\text { oil\&chemical industry, telecommunication } \\
\text { companies, and companies from other sectors. }\end{array}$ \\
\hline LiquidityC & $\begin{array}{l}\text { Liquidity of common } \\
\text { shares }\end{array}$ & $\begin{array}{l}\text { Ratio of the ask and bid prices of common } \\
\text { shares. }\end{array}$ \\
\hline LiquidityP & $\begin{array}{l}\text { Liquidity of preferred } \\
\text { shares }\end{array}$ & $\begin{array}{l}\text { Ratio of the ask and bid prices of preferred } \\
\text { shares. }\end{array}$ \\
\hline DateC & $\begin{array}{l}\text { Deviation of common } \\
\text { share trade from April } 1\end{array}$ & $\begin{array}{l}\text { Number of days between the date common } \\
\text { shares were traded and April } 1 .\end{array}$ \\
\hline DateP & $\begin{array}{l}\text { Deviation of preferred } \\
\text { share trade from April } 1\end{array}$ & $\begin{array}{l}\text { Number of days between the date preferred } \\
\text { shares were traded and April } 1 .\end{array}$ \\
\hline$\Phi$ & $\begin{array}{l}\text { Proxy for control contest } \\
\text { probability }\end{array}$ & Shapley value.* \\
\hline$\pi$ & $\begin{array}{l}\text { Share of voting stock in } \\
\text { company's equity }\end{array}$ & Share of voting stock in company's equity. \\
\hline$\Delta$ Dividend & $\begin{array}{l}\text { Measure of differential } \\
\text { dividend }\end{array}$ & $\begin{array}{l}\text { Difference between latest annual dividends on } \\
\text { preferred and common shares divided by the } \\
\text { price of preferred shares. }\end{array}$ \\
\hline Dividend10 & $\begin{array}{l}\text { Particular dividend rule for } \\
\text { preferred shares }\end{array}$ & $\begin{array}{l}\text { Equals } 1 \text { if a company allocates } 10 \text { percent of its } \\
\text { net profit to dividends on preferred stock. }\end{array}$ \\
\hline Enfranch & $\begin{array}{l}\text { Temporarily enfranchised } \\
\text { preferred stock }\end{array}$ & $\begin{array}{l}\text { Equals } 1 \text { if preferred shares get full voting rights } \\
\text { (in case of zero dividend on preferred shares in } \\
\text { the last financial year). }\end{array}$ \\
\hline ADR & $\begin{array}{l}\text { Proxy for corporate } \\
\text { transparency }\end{array}$ & $\begin{array}{l}\text { Equals } 1 \text { if a company cross-lists its shares in the } \\
\text { U.S. stock market. }\end{array}$ \\
\hline Tobin’s Q & Tobin’s Q & $\begin{array}{l}\text { Market value of the firms divided by the book } \\
\text { value of equity. }\end{array}$ \\
\hline Ln(Equity) & Size of the firm & Logarithm of the firm's equity. \\
\hline
\end{tabular}


Table 3. The voting premium in 2000, 2001, and 2002.

\begin{tabular}{lcccccc}
\hline year & $\mu$ & $\sigma$ & min & p50 & $\max$ & $\mathrm{N}$ \\
\hline \multicolumn{7}{c}{ Control group } \\
\hline 2000 & 1.729 & 0.680 & 0.633 & 1.800 & 3.051 & 23 \\
2001 & 1.134 & 0.612 & 0.194 & 1.037 & 2.548 & 25 \\
2002 & 0.753 & 0.384 & 0.056 & 0.761 & 1.417 & 28 \\
Total & 1.174 & 0.685 & 0.056 & 1.063 & 3.051 & 76 \\
\hline \multicolumn{7}{c}{ Treatment group } \\
\hline 2000 & 2.184 & 0.932 & 0.471 & 2.091 & 4.500 & 45 \\
2001 & 1.608 & 0.706 & 0.154 & 1.600 & 3.437 & 57 \\
2002 & 0.915 & 0.418 & 0.041 & 0.862 & 2.409 & 68 \\
Total & 1.483 & 0.852 & 0.041 & 1.266 & 4.500 & 170 \\
\hline \hline
\end{tabular}


Table 4. Baseline estimates of the effect of the change in law on the voting premium.

\begin{tabular}{|c|c|c|c|c|}
\hline & $\begin{array}{c}1 \\
\text { OLS }\end{array}$ & $\begin{array}{c}2 \\
\text { OLS }\end{array}$ & $\begin{array}{c}3 \\
\text { OLS } \\
\end{array}$ & $\begin{array}{c}4 \\
\text { OLS } \\
\end{array}$ \\
\hline TrGroup*Time & $\begin{array}{c}-0.312^{* *} \\
(0.145)\end{array}$ & $\begin{array}{c}-0.302^{* *} \\
(0.148)\end{array}$ & $\begin{array}{c}-0.296^{*} \\
(0.154)\end{array}$ & $\begin{array}{c}-0.331^{* *} \\
(0.150)\end{array}$ \\
\hline Time & $\begin{array}{c}-0.381 * * * \\
(0.111)\end{array}$ & $\begin{array}{c}-0.382 * * * \\
(0.116)\end{array}$ & $\begin{array}{c}-0.411 * * * \\
(0.139)\end{array}$ & $\begin{array}{c}-0.379 * * * \\
(0.139)\end{array}$ \\
\hline TrGroup & $\begin{array}{c}0.474 * * * \\
(0.154)\end{array}$ & $\begin{array}{c}0.477^{* *} \\
(0.211)\end{array}$ & $\begin{array}{l}0.439^{*} \\
(0.223)\end{array}$ & $\begin{array}{c}0.513 * * \\
(0.221)\end{array}$ \\
\hline Energos & & $\begin{array}{c}0.013 \\
(0.184)\end{array}$ & $\begin{array}{l}-0.004 \\
(0.193)\end{array}$ & $\begin{array}{c}0.029 \\
(0.184)\end{array}$ \\
\hline Oil\&Chemical & & $\begin{array}{l}-0.065 \\
(0.156)\end{array}$ & $\begin{array}{l}-0.039 \\
(0.151)\end{array}$ & $\begin{array}{l}-0.129 \\
(0.168)\end{array}$ \\
\hline Others & & $\begin{array}{c}0.344 \\
(0.362)\end{array}$ & $\begin{array}{c}0.343 \\
(0.327)\end{array}$ & $\begin{array}{c}0.147 \\
(0.481)\end{array}$ \\
\hline LiquidityC & & & $\begin{array}{l}0.601^{*} \\
(0.354)\end{array}$ & $\begin{array}{c}0.310 \\
(0.326)\end{array}$ \\
\hline LiquidityP & & & $\begin{array}{c}-0.570 * * \\
(0.272)\end{array}$ & $\begin{array}{c}-0.573 * * \\
(0.281)\end{array}$ \\
\hline DateC & & & $\begin{array}{c}-0.000 \\
(0.002)\end{array}$ & $\begin{array}{c}0.000 \\
(0.002)\end{array}$ \\
\hline DateP & & & $\begin{array}{l}-0.002 \\
(0.002)\end{array}$ & $\begin{array}{l}-0.002 \\
(0.002)\end{array}$ \\
\hline$\Phi / \pi$ & & & & $\begin{array}{c}1.033 \\
(1.200)\end{array}$ \\
\hline$\Delta$ Dividend & & & & $\begin{array}{l}-0.609 \\
(0.812)\end{array}$ \\
\hline Dividend10 & & & & $\begin{array}{l}-0.205 \\
(0.260)\end{array}$ \\
\hline Enfranch & & & & $\begin{array}{c}-0.110 \\
(0.166)\end{array}$ \\
\hline ADR & & & & $\begin{array}{c}0.116 \\
(0.114)\end{array}$ \\
\hline Intercept & $\begin{array}{c}1.134 * * * \\
(0.121)\end{array}$ & $\begin{array}{c}1.116^{* * *} \\
(0.195)\end{array}$ & $\begin{array}{c}1.078 * * * \\
(0.229)\end{array}$ & $\begin{array}{c}1.433^{* * *} * \\
(0.374) \\
\end{array}$ \\
\hline $\begin{array}{l}\text { R-squared } \\
\text { No. obs. }\end{array}$ & $\begin{array}{l}.28 \\
178\end{array}$ & $\begin{array}{l}.29 \\
178\end{array}$ & $\begin{array}{c}.32 \\
178\end{array}$ & $\begin{array}{c}.36 \\
178\end{array}$ \\
\hline
\end{tabular}

The regressions are estimated using OLS. The dependent variable is the voting premium, $V P$. Telecoms is the omitted industry dummy. Cluster-robust standard errors (clustering by company) are reported in parentheses. Asterisks denote significance levels: 1 percent $(* * *), 5$ percent $(* *)$, and 10 percent $(*)$. 
Table 5. Additional estimates of the effect of the change in law on the voting premium (1).

\begin{tabular}{|c|c|c|c|c|c|c|}
\hline & $\begin{array}{c}1 \\
\mathrm{FE}\end{array}$ & $\begin{array}{c}2 \\
\mathrm{FE}\end{array}$ & $\begin{array}{c}3 \\
\text { Quantile }\end{array}$ & $\begin{array}{c}4 \\
\text { Quantile }\end{array}$ & $\begin{array}{c}5 \\
\text { OLS-2000/2 }\end{array}$ & $\begin{array}{c}6 \\
\text { OLS-2000/2 } \\
\end{array}$ \\
\hline TrGroup*Time & $\begin{array}{c}-0.265 * \\
(0.142)\end{array}$ & $\begin{array}{c}-0.289 * * \\
(0.135)\end{array}$ & $\begin{array}{c}-0.343^{*} \\
(0.184)\end{array}$ & $\begin{array}{c}-0.273 \\
(0.170)\end{array}$ & $\begin{array}{c}-0.293 \\
(0.192)\end{array}$ & $\begin{array}{c}-0.373 * \\
(0.198)\end{array}$ \\
\hline Time & $\begin{array}{c}-0.398 * * * \\
(0.106)\end{array}$ & $\begin{array}{c}-0.531^{* * *} \\
(0.154)\end{array}$ & $\begin{array}{c}-0.393^{* *} \\
(0.153)\end{array}$ & $\begin{array}{c}-0.420 * * * \\
(0.154)\end{array}$ & $\begin{array}{c}-0.978^{* * *} \\
(0.130)\end{array}$ & $\begin{array}{c}-1.035^{* * *} \\
(0.156)\end{array}$ \\
\hline TrGroup & & & $\begin{array}{c}0.351^{* *} \\
(0.156)\end{array}$ & $\begin{array}{c}0.371^{* *} \\
(0.148)\end{array}$ & $\begin{array}{c}0.308 \\
(0.212)\end{array}$ & $\begin{array}{c}0.339 * \\
(0.196)\end{array}$ \\
\hline Energos & & & $\begin{array}{l}-0.212^{*} \\
(0.126)\end{array}$ & $\begin{array}{l}-0.190 \\
(0.118)\end{array}$ & $\begin{array}{l}-0.317^{*} \\
(0.166)\end{array}$ & $\begin{array}{c}-0.360^{* *} \\
(0.168)\end{array}$ \\
\hline Oil\&Chemical & & & $\begin{array}{c}0.094 \\
(0.130)\end{array}$ & $\begin{array}{l}-0.150 \\
(0.134)\end{array}$ & $\begin{array}{l}-0.210 \\
(0.183)\end{array}$ & $\begin{array}{l}-0.260 \\
(0.208)\end{array}$ \\
\hline Others & & & $\begin{array}{c}0.189 \\
(0.190)\end{array}$ & $\begin{array}{l}-0.223 \\
(0.225)\end{array}$ & $\begin{array}{l}-0.253 \\
(0.292)\end{array}$ & $\begin{array}{l}-0.364 \\
(0.283)\end{array}$ \\
\hline LiquidityC & & $\begin{array}{c}0.665 \\
(0.457)\end{array}$ & & $\begin{array}{c}0.344 \\
(0.327)\end{array}$ & & $\begin{array}{c}0.949 * * \\
(0.447)\end{array}$ \\
\hline LiquidityP & & $\begin{array}{l}-0.212 \\
(0.314)\end{array}$ & & $\begin{array}{c}-0.421^{*} \\
(0.237)\end{array}$ & & $\begin{array}{l}-0.341 \\
(0.363)\end{array}$ \\
\hline DateC & & $\begin{array}{c}0.002 \\
(0.003)\end{array}$ & & $\begin{array}{c}-0.003^{* *} \\
(0.002)\end{array}$ & & $\begin{array}{l}-0.003 \\
(0.003)\end{array}$ \\
\hline DateP & & $\begin{array}{c}-0.004^{*} \\
(0.002)\end{array}$ & & $\begin{array}{c}0.002 \\
(0.002)\end{array}$ & & $\begin{array}{c}0.001 \\
(0.004)\end{array}$ \\
\hline$\Phi / \pi$ & & $\begin{array}{c}5.521 * * * \\
(1.424)\end{array}$ & & $\begin{array}{c}1.368^{* * * *} \\
(0.496)\end{array}$ & & $\begin{array}{c}0.130 \\
(0.377)\end{array}$ \\
\hline$\Delta$ Dividend & & $\begin{array}{c}-2.679 * * * \\
(0.495)\end{array}$ & & $\begin{array}{c}0.360 \\
(0.412)\end{array}$ & & $\begin{array}{c}-0.237 \\
(0.679)\end{array}$ \\
\hline Dividend10 & & & & $\begin{array}{c}-0.465^{* *} \\
(0.192)\end{array}$ & & $\begin{array}{c}-0.488 * * \\
(0.215)\end{array}$ \\
\hline Enfranch & & $\begin{array}{c}0.153 \\
(0.202)\end{array}$ & & $\begin{array}{c}0.069 \\
(0.155)\end{array}$ & & $\begin{array}{c}0.044 \\
(0.144)\end{array}$ \\
\hline ADR & & $\begin{array}{c}-0.139 \\
(0.173)\end{array}$ & & $\begin{array}{c}0.027 \\
(0.101)\end{array}$ & & $\begin{array}{c}-0.252^{* *} \\
(0.106)\end{array}$ \\
\hline Intercept & $\begin{array}{c}1.435^{* * *} \\
(0.037)\end{array}$ & $\begin{array}{c}1.125^{* * *} \\
(0.328)\end{array}$ & $\begin{array}{c}1.249 * * * \\
(0.145)\end{array}$ & $\begin{array}{c}1.679 * * * \\
(0.297)\end{array}$ & $\begin{array}{c}1.951^{* * *} \\
(0.166)\end{array}$ & $\begin{array}{c}2.037 * * * \\
(0.304) \\
\end{array}$ \\
\hline R-squared & .48 & .64 & 0.17 & 0.22 & .49 & .54 \\
\hline No. obs. & 146 & 146 & 178 & 178 & 164 & 164 \\
\hline
\end{tabular}

The dependent variable is the voting premium, $V P$. Telecoms is the omitted industry dummy. Cluster-robust standard errors (clustering by company) are reported in parentheses for models 1,2 as well as 5 and 6 . Asterisks denote significance levels: 1 percent $(* * *), 5$ percent $(* *)$, and 10 percent $\left({ }^{*}\right)$. Pseudo R-squared is reported for quantile regressions in columns 3 and 4. 
Table 6. Additional estimates of the effect of the change in law on the voting premium (2).

\begin{tabular}{|c|c|c|c|c|}
\hline & $\begin{array}{c}1 \\
\text { OLS May01-Jan02 }\end{array}$ & $\begin{array}{c}2 \\
\text { OLS May01-Jan02 }\end{array}$ & $\begin{array}{c}3 \\
\text { OLS Jun01-Sep01 }\end{array}$ & $\begin{array}{c}4 \\
\text { OLS Jun01-Sep01 }\end{array}$ \\
\hline TrGroup*Time & $\begin{array}{c}-0.280 * * \\
(0.128)\end{array}$ & $\begin{array}{c}-0.278^{* *} \\
(0.134)\end{array}$ & $\begin{array}{l}-0.224^{*} \\
(0.116)\end{array}$ & $\begin{array}{c}-0.233^{*} \\
(0.118)\end{array}$ \\
\hline Time & $\begin{array}{l}-0.005 \\
(0.096)\end{array}$ & $\begin{array}{c}0.015 \\
(0.102)\end{array}$ & $\begin{array}{c}0.077 \\
(0.099)\end{array}$ & $\begin{array}{c}0.093 \\
(0.103)\end{array}$ \\
\hline TrGroup & $\begin{array}{l}0.405^{* *} \\
(0.178)\end{array}$ & $\begin{array}{l}0.421 * * \\
(0.172)\end{array}$ & $\begin{array}{l}0.303^{* *} \\
(0.152)\end{array}$ & $\begin{array}{c}0.337^{* *} \\
(0.143)\end{array}$ \\
\hline Energos & $\begin{array}{c}-0.102 \\
(0.163)\end{array}$ & $\begin{array}{l}-0.088 \\
(0.163)\end{array}$ & $\begin{array}{l}-0.195 \\
(0.167)\end{array}$ & $\begin{array}{l}-0.136 \\
(0.165)\end{array}$ \\
\hline Oil\&Chemical & $\begin{array}{l}-0.027 \\
(0.156)\end{array}$ & $\begin{array}{l}-0.086 \\
(0.228)\end{array}$ & $\begin{array}{l}-0.199 \\
(0.135)\end{array}$ & $\begin{array}{l}-0.184 \\
(0.201)\end{array}$ \\
\hline Others & $\begin{array}{c}0.146 \\
(0.175)\end{array}$ & $\begin{array}{l}-0.010 \\
(0.285)\end{array}$ & $\begin{array}{c}0.283 \\
(0.246)\end{array}$ & $\begin{array}{c}0.205 \\
(0.351)\end{array}$ \\
\hline LiquidityC & & $\begin{array}{l}-0.217 \\
(0.187)\end{array}$ & & $\begin{array}{l}-0.172 \\
(0.134)\end{array}$ \\
\hline LiquidityP & & $\begin{array}{l}-0.443 \\
(1.528)\end{array}$ & & $\begin{array}{l}-0.488 \\
(1.432)\end{array}$ \\
\hline$\Phi / \pi$ & & $\begin{array}{c}0.587 \\
(0.792)\end{array}$ & & $\begin{array}{c}0.717 \\
(0.770)\end{array}$ \\
\hline$\Delta$ Dividend & & $\begin{array}{l}-2.478 \\
(1.977)\end{array}$ & & $\begin{array}{l}-0.843 \\
(1.948)\end{array}$ \\
\hline Dividend10 & & $\begin{array}{l}-0.104 \\
(0.267)\end{array}$ & & $\begin{array}{c}0.073 \\
(0.261)\end{array}$ \\
\hline Enfranch & & $\begin{array}{l}-0.027 \\
(0.159)\end{array}$ & & $\begin{array}{l}-0.138 \\
(0.154)\end{array}$ \\
\hline ADR & & $\begin{array}{c}0.159 \\
(0.105)\end{array}$ & & $\begin{array}{c}0.102 \\
(0.113)\end{array}$ \\
\hline Intercept & $\begin{array}{c}0.890 * * * \\
(0.170)\end{array}$ & $\begin{array}{c}0.952 * * * \\
(0.324)\end{array}$ & $\begin{array}{c}1.045^{* * *} \\
(0.150)\end{array}$ & $\begin{array}{c}0.921^{* * *} \\
(0.298)\end{array}$ \\
\hline $\begin{array}{l}\text { R-squared } \\
\text { No. obs. }\end{array}$ & $\begin{array}{l}.15 \\
176\end{array}$ & $\begin{array}{l}.19 \\
176 \\
\end{array}$ & $\begin{array}{c}.13 \\
174 \\
\end{array}$ & $\begin{array}{l}.16 \\
174 \\
\end{array}$ \\
\hline
\end{tabular}

The regressions are estimated using OLS. The dependent variable is the voting premium, $V P$. Telecoms is the omitted industry dummy. Cluster-robust standard errors (clustering by company) are reported in parentheses. Asterisks denote significance levels: 1 percent $\left({ }^{* * *}\right), 5$ percent $(* *)$, and 10 percent $\left(^{*}\right)$. 
Table 7. Estimates of the effect of the change in law on Tobin's Q.

\begin{tabular}{|c|c|c|c|c|c|c|}
\hline & $\begin{array}{c}1 \\
\text { OLS }\end{array}$ & $\begin{array}{c}2 \\
\text { OLS }\end{array}$ & $\begin{array}{c}3 \\
\mathrm{FE}\end{array}$ & $\begin{array}{c}4 \\
\mathrm{FE}\end{array}$ & $\begin{array}{c}5 \\
\text { Quantile }\end{array}$ & $\begin{array}{c}6 \\
\text { Quantile }\end{array}$ \\
\hline \multirow[t]{2}{*}{ TrGroup*Time } & 0.122 & $0.174^{*}$ & $0.195^{*}$ & $0.218^{*}$ & $0.225^{* *}$ & $0.194 * *$ \\
\hline & $(0.103)$ & $(0.091)$ & $(0.100)$ & $(0.115)$ & $(0.096)$ & $(0.088)$ \\
\hline \multirow[t]{2}{*}{ Time } & $0.229 * * *$ & 0.083 & $0.253 * * *$ & $0.125^{*}$ & $0.181 * *$ & 0.067 \\
\hline & $(0.058)$ & $(0.104)$ & $(0.064)$ & $(0.075)$ & $(0.081)$ & $(0.078)$ \\
\hline \multirow[t]{2}{*}{ TrGroup } & -0.112 & -0.126 & & & $-0.212 * * *$ & $-0.204 * * *$ \\
\hline & $(0.114)$ & $(0.084)$ & & & $(0.080)$ & $(0.075)$ \\
\hline \multirow[t]{2}{*}{ Energos } & $-0.726 * * *$ & $-0.633 * * *$ & & & $-0.677 * * *$ & $-0.654 * * *$ \\
\hline & $(0.091)$ & $(0.096)$ & & & $(0.065)$ & $(0.063)$ \\
\hline \multirow[t]{2}{*}{ Oil\&Chemical } & 0.230 & 0.362 & & & $-0.122 *$ & $-0.145^{* *}$ \\
\hline & $(0.339)$ & $(0.436)$ & & & $(0.068)$ & $(0.072)$ \\
\hline \multirow[t]{2}{*}{ Others } & $-0.341 * * *$ & -0.171 & & & $-0.367 * * *$ & $-0.457 * * *$ \\
\hline & $(0.127)$ & $(0.266)$ & & & (0.099) & $(0.121)$ \\
\hline \multirow[t]{2}{*}{ LiquidityC } & & 0.055 & & 0.430 & & -0.131 \\
\hline & & $(0.272)$ & & $(0.403)$ & & $(0.166)$ \\
\hline \multirow[t]{2}{*}{ LiquidityP } & & $0.476 * *$ & & 0.019 & & $0.560 * * *$ \\
\hline & & $(0.237)$ & & $(0.279)$ & & $(0.124)$ \\
\hline \multirow[t]{2}{*}{ DateC } & & -0.000 & & -0.003 & & 0.001 \\
\hline & & $(0.001)$ & & $(0.002)$ & & $(0.001)$ \\
\hline \multirow[t]{2}{*}{ DateP } & & 0.000 & & 0.002 & & -0.001 \\
\hline & & $(0.001)$ & & $(0.002)$ & & $(0.001)$ \\
\hline \multirow[t]{2}{*}{$\Phi / \pi$} & & -0.535 & & -0.263 & & -0.052 \\
\hline & & $(0.427)$ & & (1.167) & & $(0.244)$ \\
\hline \multirow[t]{2}{*}{$\Delta$ Dividend } & & -0.381 & & -0.671 & & $-0.483^{* *}$ \\
\hline & & $(0.442)$ & & $(0.487)$ & & $(0.220)$ \\
\hline \multirow[t]{2}{*}{ Dividend10 } & & 0.370 & & & & $0.347 * * *$ \\
\hline & & $(0.400)$ & & & & $(0.101)$ \\
\hline \multirow[t]{2}{*}{ Enfranch } & & -0.048 & & 0.238 & & 0.091 \\
\hline & & $(0.228)$ & & $(0.143)$ & & $(0.084)$ \\
\hline \multirow[t]{2}{*}{ ADR } & & $0.229^{*}$ & & $0.480^{*}$ & & $0.283 * * *$ \\
\hline & & $(0.129)$ & & $(0.267)$ & & $(0.056)$ \\
\hline \multirow[t]{2}{*}{ Intercept } & $0.814 * * *$ & 0.112 & $0.555^{* * *}$ & 0.167 & $0.756 * * *$ & 0.213 \\
\hline & $(0.103)$ & $(0.540)$ & $(0.028)$ & $(0.214)$ & $(0.075)$ & $(0.156)$ \\
\hline R-squared & .30 & .38 & .41 & .48 & 0.32 & 0.41 \\
\hline No. obs. & 178 & 178 & 146 & 146 & 178 & 178 \\
\hline
\end{tabular}

The dependent variable is Tobin's Q. Telecoms is the omitted industry dummy. Cluster-robust standard errors (clustering by company) are reported in parentheses for models 1-4. Asterisks denote significance levels: 1 percent $(* * *)$, 5 percent $(* *)$, and 10 percent $(*)$. Pseudo R-squared is reported for the quantile regressions in columns 5 and 6 . 
Appendix 1. Provisions in Russia's corporate law concerning the veto power of preferred shareholders

The excerpts below show how Russia’s legislative acts from 1992, 1995 and 2001 defined the voting rights of preferred shareholders in the event of changes in corporate charters that involved the interests of these investors. All these legislative acts explicitly state that preferred shareholders do not vote on usual issues, such as election of corporate boards.

I. Excerpt from the "standard corporate charter" introduced by Presidential decree No. 721 dated 1 July, 1992 "On organizational measures on transformation of state enterprises, voluntary associations of state enterprises into joint-stock companies”:

Article 5. Rights and duties of shareholders

\subsection{Rights of shareholders-possessors of preferred shares}

Shareholders-possessors of type A preferred shares ${ }^{1}$ do not have the right to vote at shareholder meetings except for the instances when changes in and additions to this charter concern reorganization or liquidation of the company, changes in the amount of dividend to be paid on type A preferred shares or issue of other types of preferred shares that give their possessors more extensive rights compared with the rights granted by this charter to the shareholders-possessors of type A preferred shares. In such a case, the decision must be approved by two thirds of type A preferred shareholders.

II. Excerpt from Federal law “On joint-stock companies” N 208 FZ, dated 26 December, 1995:

Article 32. Rights of shareholders-possessors of preferred shares

3. Shareholders-possessors of preferred shares shall participate in general shareholder meetings with the right of vote when deciding questions concerning reorganization and liquidation of the company. The shareholders-possessors of preferred shares of a specified type shall acquire the right to vote when deciding questions at general shareholder meetings concerning changes in and additions to the company charter which limit the rights of shareholders-possessors of this type of preferred shares, including instances of the

\footnotetext{
${ }^{1}$ Type B preferred shares represent a short-lived phenomenon of the 1990s and are not relevant for this study. They were shares that were supposed to be sold to private persons during the privatization process, but that temporarily remained in the hands of the government. The rights attached to these shares were identical to those of common ones, except for the voting right (type B preferred shares were non-voting). A transfer of these shares from the government to private ownership implied their automatic conversion into common shares.
} 
determining or increasing the amount of dividend and/or determining or increasing the liquidation value of preferred shares of a preceding priority, and also concerning granting preferences in the priority of payment of a dividend and/or liquidation value of shares to shareholders-possessors of another type of preferred shares.

III. Excerpt from Federal law “On joint-stock companies” N 208 FZ in the edition of the Federal law N 120 FZ, dated 7 August 2001:

Article 32. Rights of stockholders-possessors of preferred shares

4. Shareholders-possessors of preferred shares shall participate in general shareholder meetings with the right of vote when deciding questions concerning reorganization and liquidation of the company. The shareholders-possessors of preferred shares of a specified type shall acquire the right to vote when deciding questions at general shareholder meetings concerning changes in and additions to the company charter, which limit the rights of shareholders-possessors of this type of preferred shares, including instances of the determining or increasing the amount of dividend and/or determining or increasing the liquidation value of preferred shares of a preceding priority, and also concerning granting preferences in the priority of payment of a dividend and/or liquidation value of shares to shareholders-possessors of another type of preferred shares. The resolutions on making such changes and additions shall be considered approved if they receive not less that three quarters of the votes of the shareholders-possessors of common shares participating in the shareholder meeting, except for the votes of the shareholders-possessors of preferred shares, whose rights are being restricted, and three quarters of the votes of the shareholderspossessors of preferred shares of each type, whose rights are being restricted, unless the charter specifies a higher number of shareholder votes for the approval of such resolutions. 
Appendix 2. The long road to the new law on joint-stock companies.

\begin{tabular}{|c|c|}
\hline Date & Event \\
\hline 10 Jan 1999 & $\begin{array}{l}\text { Approved by the profile committee of State Duma* and forwarded to the State } \\
\text { Duma council }\end{array}$ \\
\hline 14 Apr 1999 & Approved by State Duma in $1^{\text {st }}$ reading (Resolution N 3872-II GD) \\
\hline 19 Apr 2000 & Approved by State Duma in $2^{\text {nd }}$ reading (Resolution N 305-III GD) \\
\hline 02 Jun 2000 & Approved by State Duma in $3^{\text {rd }}$ reading (Resolution N 437-III GD) \\
\hline 07 Jun 2000 & Rejected by Council of Federation** (Resolution N 143-SF) ${ }^{* * *}$ \\
\hline 21 Jun 2000 & Conciliatory commission formed (Resolution N 477-III GD) \\
\hline 08 Dec 2000 & $\begin{array}{l}\text { Approved by State Duma in } 3^{\text {rd }} \text { reading in the edition of the conciliatory } \\
\text { commission (Resolution N 904-III GD) }\end{array}$ \\
\hline 20 Dec 2000 & Rejected by Council of Federation (Resolution N 328-SF) ${ }^{\mathrm{a}}$ \\
\hline 13 Jun 2001 & Conciliatory commission formed (Resolution N 1605-III GD) \\
\hline 12 Jul 2001 & Approved by State Duma as a whole in the edition of the conciliatory commission \\
\hline $20 \mathrm{Jul} 2001$ & Approved by Council of Federation \\
\hline 07 Aug 2001 & Signed by President of the Russian Federation*** \\
\hline 01 Jan 2002 & Entered into force \\
\hline
\end{tabular}

* State Duma is the lower chamber of Russia's parliament.

** Council of Federation is the upper chamber of Russia's parliament.

*** Enactment of a law requires approval by both chambers as well as by President, who has a veto right.

a According to Russian mass media, the law initially faced considerable opposition from the communist fraction in the parliament (the largest until January 2000, with 31.4 percent of seats), which proposed over 300 changes and amendments to the document. Arguably, the intention of the communists was to protect managers, most of whom were appointed in the Soviet time, from the growing pressure of shareholders. Later the law was torpedoed in Council of Federation thanks to lobbying effort on the part of large monopolistic enterprises. A key issue, according to mass media reports, was the norm in the new law that allowed firing of CEOs by simple majority of votes rather than qualified majority, which was stipulated in many charters. The reintroduction in the law of the veto power of preferred shareholders was hardly a major issue in this political game. 
Appendix 3. Baseline estimates of the effect of the change in law on the voting premium with winsorized (10\%) values of the dependent variable.

\begin{tabular}{|c|c|c|c|c|}
\hline & $\begin{array}{c}1 \\
\text { OLS }\end{array}$ & $\begin{array}{c}2 \\
\text { OLS }\end{array}$ & $\begin{array}{c}3 \\
\text { OLS }\end{array}$ & $\begin{array}{c}4 \\
\text { OLS }\end{array}$ \\
\hline TrGroup*Time & $\begin{array}{c}-0.291 * \\
(0.164)\end{array}$ & $\begin{array}{c}-0.280^{*} \\
(0.166)\end{array}$ & $\begin{array}{c}-0.313^{*} \\
(0.167)\end{array}$ & $\begin{array}{c}-0.338 * * \\
(0.166)\end{array}$ \\
\hline Time & $\begin{array}{c}-0.377^{* * *} \\
(0.138)\end{array}$ & $\begin{array}{c}-0.382 * * * \\
(0.141)\end{array}$ & $\begin{array}{c}-0.392 * * \\
(0.154)\end{array}$ & $\begin{array}{c}-0.371^{* *} \\
(0.154)\end{array}$ \\
\hline TrGroup & $\begin{array}{c}0.406^{* *} \\
(0.171)\end{array}$ & $\begin{array}{c}0.348^{*} \\
(0.208)\end{array}$ & $\begin{array}{c}0.333 \\
(0.212)\end{array}$ & $\begin{array}{l}0.372 * \\
(0.203)\end{array}$ \\
\hline Energos & & $\begin{array}{c}-0.093 \\
(0.149)\end{array}$ & $\begin{array}{c}-0.087 \\
(0.154)\end{array}$ & $\begin{array}{l}-0.061 \\
(0.144)\end{array}$ \\
\hline Oil\&Chemical & & $\begin{array}{c}-0.044 \\
(0.144)\end{array}$ & $\begin{array}{l}-0.007 \\
(0.138)\end{array}$ & $\begin{array}{l}-0.059 \\
(0.149)\end{array}$ \\
\hline Others & & $\begin{array}{c}0.175 \\
(0.256)\end{array}$ & $\begin{array}{c}0.209 \\
(0.212)\end{array}$ & $\begin{array}{c}0.173 \\
(0.337)\end{array}$ \\
\hline LiquidityC & & & $\begin{array}{c}0.534 \\
(0.353)\end{array}$ & $\begin{array}{c}0.320 \\
(0.357)\end{array}$ \\
\hline LiquidityP & & & $\begin{array}{c}-0.557 * * \\
(0.259)\end{array}$ & $\begin{array}{c}-0.572 * * \\
(0.263)\end{array}$ \\
\hline DateC & & & $\begin{array}{c}0.002 \\
(0.001)\end{array}$ & $\begin{array}{c}0.002 \\
(0.002)\end{array}$ \\
\hline DateP & & & $\begin{array}{c}-0.005^{* * *} \\
(0.002)\end{array}$ & $\begin{array}{c}-0.005^{* * *} \\
(0.002)\end{array}$ \\
\hline$\Phi / \pi$ & & & & $\begin{array}{c}0.480 \\
(0.880)\end{array}$ \\
\hline$\Delta$ Dividend & & & & $\begin{array}{l}-0.497 \\
(0.707)\end{array}$ \\
\hline Dividend10 & & & & $\begin{array}{l}-0.171 \\
(0.222)\end{array}$ \\
\hline Enfranch & & & & $\begin{array}{l}-0.164 \\
(0.147)\end{array}$ \\
\hline ADR & & & & $\begin{array}{c}0.102 \\
(0.108)\end{array}$ \\
\hline Intercept & $\begin{array}{c}1.150^{* * *} \\
(0.148)\end{array}$ & $\begin{array}{c}1.210^{* * *} \\
(0.197) \\
\end{array}$ & $\begin{array}{c}1.192 * * * \\
(0.234) \\
\end{array}$ & $\begin{array}{c}1.500 * * * \\
(0.339) \\
\end{array}$ \\
\hline $\begin{array}{l}\text { R-squared } \\
\text { No. obs. }\end{array}$ & $\begin{array}{l}.29 \\
178\end{array}$ & $\begin{array}{l}.29 \\
178\end{array}$ & $\begin{array}{c}.34 \\
178\end{array}$ & $\begin{array}{c}.37 \\
178\end{array}$ \\
\hline
\end{tabular}

The regressions are estimated using OLS. The dependent variable is the voting premium, VP. Telecoms is the omitted industry dummy. Cluster-robust standard errors (clustering by company) are reported in parentheses. Asterisks denote significance levels: 1 percent $(* * *), 5$ percent $(* *)$, and 10 percent $(*)$. 
Appendix 4. Determinants of the abolishment of the veto power of preferred shareholders.

\begin{tabular}{lccc}
\hline \hline & 1 & 2 & 3 \\
& Probit & Probit & Probit \\
\hline Log(employment) & $-0.072^{*}$ & $-0.112^{* *}$ & $-0.131^{* * *}$ \\
& $(0.038)$ & $(0.048)$ & $(0.050)$ \\
Time since privatization, months & $-0.025^{* * *}$ & $-0.013^{*}$ & $-0.017^{* * *}$ \\
& $(0.006)$ & $(0.007)$ & $(0.007)$ \\
Energos & & $-0.497^{* * *}$ & $-0.344^{* *}$ \\
& & $(0.128)$ & $(0.166)$ \\
Oil\&Chemical & 0.083 & 0.137 \\
& & $(0.104)$ & $(0.091)$ \\
Others & $0.223^{* * *}$ & $0.245^{* * *}$ \\
& & $(0.071)$ & $(0.053)$ \\
Return on assets & & 1.301 \\
& & & $(0.950)$ \\
Time until listing in the RTS & & 0.004 \\
& & & $(0.003)$ \\
\hline R-squared & & .36 & .38 \\
No. obs. & 130 & 130 \\
\hline \hline The reported probit regressions are based on company-level data from 1996. The \\
dependent variable equals 1 if the company abolished the veto right in the mid-1990s \\
and 0 otherwise. Telecoms is the omitted industry dummy. The table shows marginal \\
effects evaluated at the mean after probit estimation. Robust standard errors are reported \\
in parentheses. Asterisks denote significance levels: 1 percent (***), 5 percent (**), and \\
10 percent $(*)$.
\end{tabular}

